\title{
LEVEL II SCOUR ANALYSIS FOR BRIDGE 26 (ROYATH00540026) on TOWN HIGHWAY 54, crossing BROAD BROOK, ROYALTON, VERMONT
}

U.S. Geological Survey Open-File Report 97-579

Prepared in cooperation with

VERMONT AGENCY OF TRANSPORTATION and

FEDERAL HIGHWAY ADMINISTRATION 


\section{LEVEL II SCOUR ANALYSIS FOR BRIDGE 26 (ROYATH00540026) on TOWN HIGHWAY 54, crossing BROAD BROOK, ROYALTON, VERMONT \\ By RONDA L. BURNS \& MATTHEW A. WEBER}

U.S. Geological Survey Open-File Report 97-579

Prepared in cooperation with

VERMONT AGENCY OF TRANSPORTATION and

FEDERAL HIGHWAY ADMINISTRATION 


\title{
U.S. DEPARTMENT OF THE INTERIOR BRUCE BABBITT, Secretary
}

\author{
U.S. GEOLOGICAL SURVEY \\ Gordon P. Eaton, Director
}

For additional information write to:

District Chief

U.S. Geological Survey 361 Commerce Way

Pembroke, NH 03275-3718
Copies of this report may be purchased from:

U.S. Geological Survey

Branch of Information Services

Open-File Reports Unit

Box 25286

Denver, CO 80225-0286 


\section{CONTENTS}

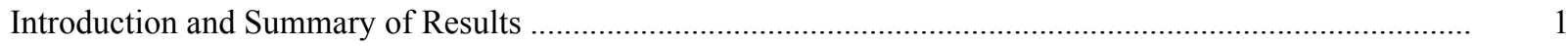

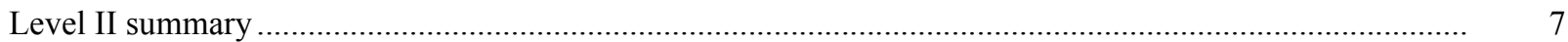

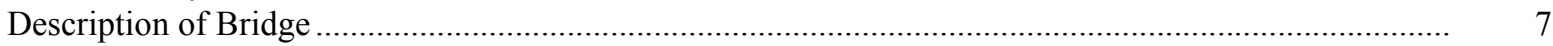

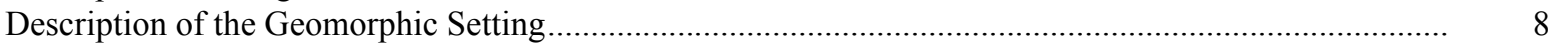

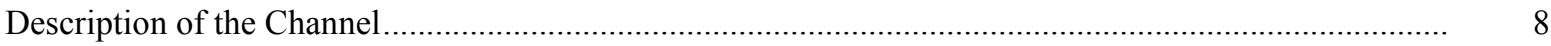

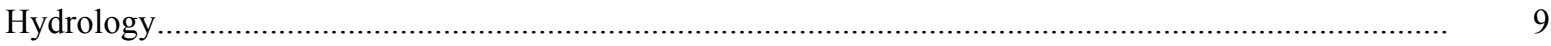

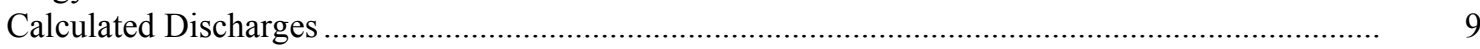

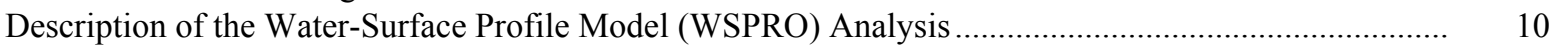

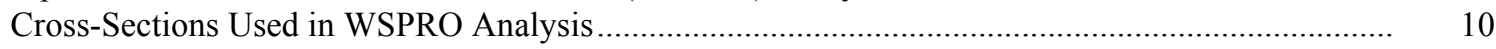

Data and Assumptions Used in WSPRO Model ...................................................................... 11

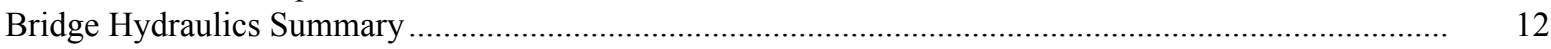

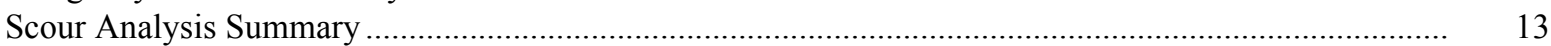

Special Conditions or Assumptions Made in Scour Analysis ...................................................... 13

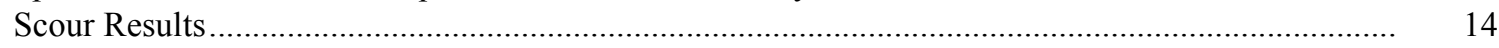

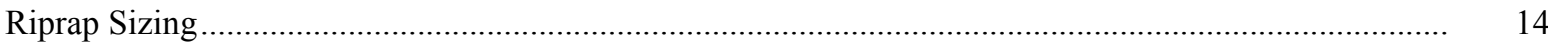

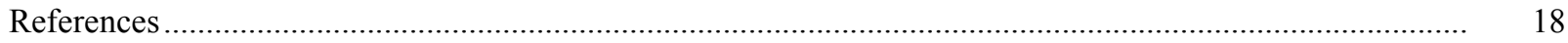

Appendixes:

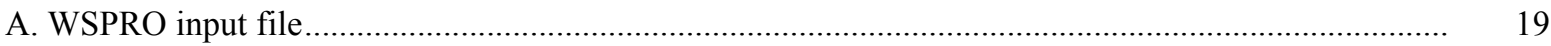

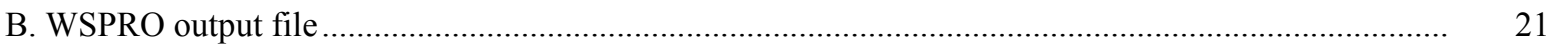

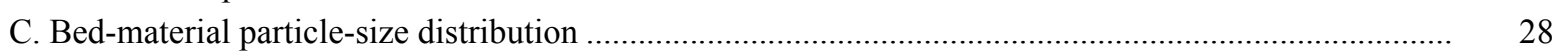

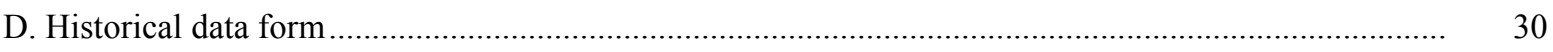

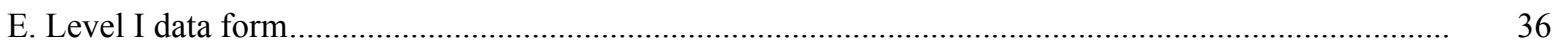

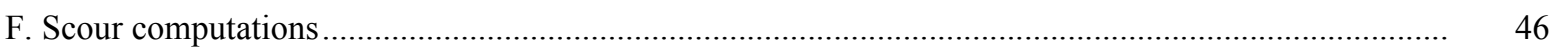

\section{FIGURES}

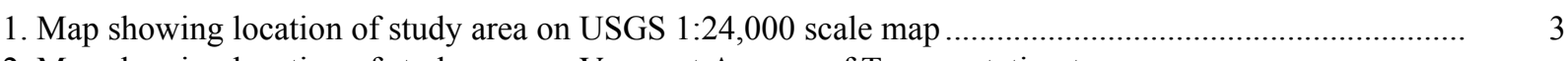

2. Map showing location of study area on Vermont Agency of Transportation town
highway map

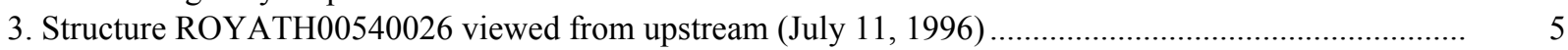

4. Downstream channel viewed from structure ROYATH00540026 (July 11, 1996). ............................... 5

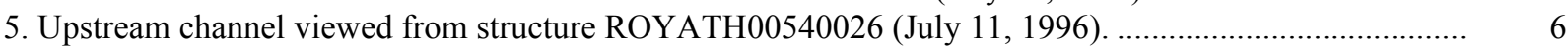

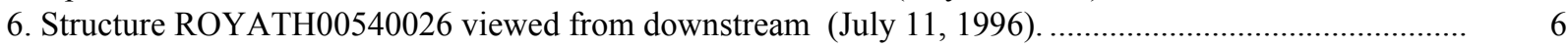

7. Water-surface profiles for the 100- and 500-year discharges at structure ROYATH00540026 on Town Highway 54, crossing Broad Brook,

Royalton, Vermont.

8. Scour elevations for the 100- and 500-year discharges at structure

ROYATH00540026 on Town Highway 54, crossing Broad Brook,

Royalton, Vermont.

\section{TABLES}

1. Remaining footing/pile depth at abutments for the 100-year discharge at structure ROYATH00540026 on Town Highway 54, crossing Broad Brook,

Royalton, Vermont.

2. Remaining footing/pile depth at abutments for the 500-year discharge at structure

ROYATH00540026 on Town Highway 54, crossing Broad Brook,

Royalton, Vermont. 


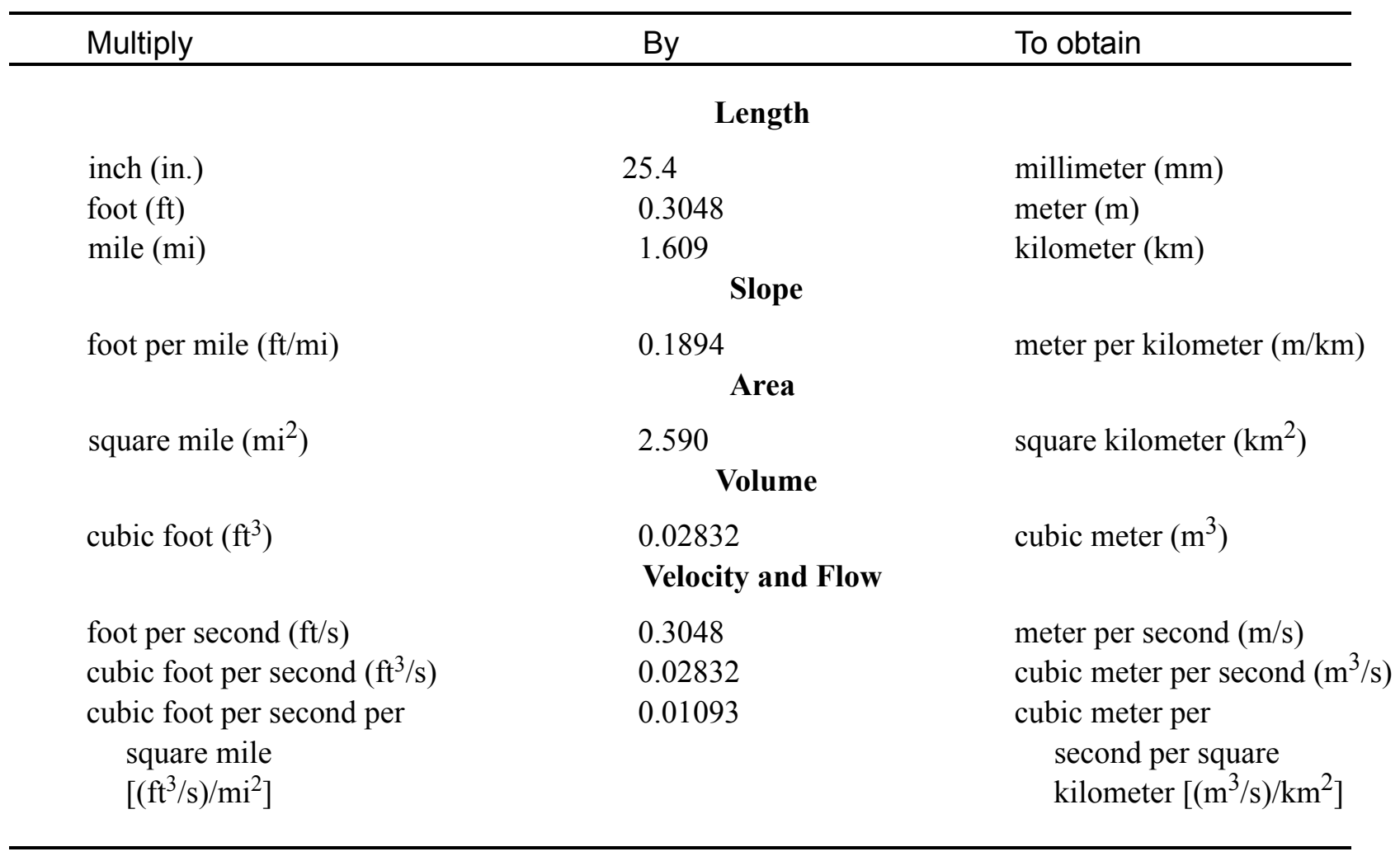

\section{OTHER ABBREVIATIONS}

$\begin{array}{lrlr}\mathrm{BF} & \text { bank full } & \text { LWW } & \text { left wingwall } \\ \mathrm{cfs} & \text { cubic feet per second } & \text { MC } & \text { main channel } \\ \mathrm{D}_{50} & \text { median diameter of bed material } & \text { RAB } & \text { right abutment } \\ \mathrm{DS} & \text { downstream } & \text { RABUT } & \text { face of right abutment } \\ \mathrm{elev} & \text { elevation } & \text { RB } & \text { right bank } \\ \mathrm{f} / \mathrm{p} & \text { flood plain } & \text { ROB } & \text { right overbank } \\ \mathrm{ft}^{2} & \text { square feet } & \text { RWW } & \text { right wingwall } \\ \mathrm{ft} / \mathrm{ft} & \text { feet per foot } & \text { TH } & \text { town highway } \\ \mathrm{JCT} & \text { junction } & \text { UB } & \text { under bridge } \\ \mathrm{LAB} & \text { left abutment } & \text { US } & \text { upstream } \\ \mathrm{LABUT} & \text { face of left abutment } & \text { USGS } & \text { United States Geological Survey } \\ \mathrm{LB} & \text { left bank } & \text { VTAOT Vermont Agency of Transportation } \\ \mathrm{LOB} & \text { left overbank } & \text { WSPRO } & \text { water-surface profile model }\end{array}$

In this report, the words "right" and "left" refer to directions that would be reported by an observer facing downstream. Sea level: In this report, "sea level" refers to the National Geodetic Vertical Datum of 1929-- a geodetic datum derived from a general adjustment of the first-order level nets of the United States and Canada, formerly called Sea Level Datum of 1929.

In the appendices, the above abbreviations may be combined. For example, USLB would represent upstream left bank. 


\title{
LEVEL II SCOUR ANALYSIS FOR BRIDGE 26 (ROYATH00540026) ON TOWN HIGHWAY 54, CROSSING BROAD BROOK, ROYALTON, VERMONT
}

\author{
By Ronda L. Burns and Matthew A. Weber
}

\section{INTRODUCTION AND SUMMARY OF RESULTS}

This report provides the results of a detailed Level II analysis of scour potential at structure ROYATH00540026 on Town Highway 54 crossing Broad Brook, Royalton, Vermont (figures 1-8). A Level II study is a basic engineering analysis of the site, including a quantitative analysis of stream stability and scour (U.S. Department of Transportation, 1993). Results of a Level I scour investigation also are included in Appendix E of this report. A Level I investigation provides a qualitative geomorphic characterization of the study site. Information on the bridge, gleaned from Vermont Agency of Transportation (VTAOT) files, was compiled prior to conducting Level I and Level II analyses and is found in Appendix D.

The site is in the New England Upland section of the New England physiographic province in central Vermont. The $11.9-\mathrm{mi}^{2}$ drainage area is in a predominantly rural and forested basin. In the vicinity of the study site, the surface cover on the left bank upstream and downstream is pasture with trees and brush on the immediate banks. The right bank, upstream and downstream of the bridge, is forested.

In the study area, Broad Brook has an incised, sinuous channel with a slope of approximately $0.01 \mathrm{ft} / \mathrm{ft}$, an average channel top width of $37 \mathrm{ft}$ and an average bank height of $4 \mathrm{ft}$. The channel bed material ranges from sand to boulders with a median grain size $\left(\mathrm{D}_{50}\right)$ of $66.3 \mathrm{~mm}(0.218 \mathrm{ft})$. The geomorphic assessment at the time of the Level I site visit on April 13, 1995 and the Level II site visit on July 11, 1996, indicated that the reach was stable.

The Town Highway 54 crossing of Broad Brook is a 29-ft-long, one-lane bridge consisting of one 24-foot steel-beam span with a timber deck (Vermont Agency of Transportation, written communication, March 23, 1995). The opening length of the structure parallel to the bridge face is $23.3 \mathrm{ft}$. The bridge is supported by a vertical, concrete face laid-up stone abutment with concrete wingwalls on the left and a laid-up stone abutment on the right. The channel is skewed approximately 20 degrees to the opening while the opening-skew-toroadway is zero degrees. 
A scour hole $1.0 \mathrm{ft}$ deeper than the mean thalweg depth was observed along the downstream end of the right abutment during the Level I assessment. Also, at the upstream end of the left abutment, the footing is exposed $0.5 \mathrm{ft}$. The scour protection measures at the site included type-2 stone fill (less than 36 inches diameter) along the upstream left bank, at the upstream end of the upstream left wingwall, along the entire length of the downstream left wingwall, and at the upstream end of the right abutment. Additional details describing conditions at the site are included in the Level II Summary and Appendices D and E.

Scour depths and recommended rock rip-rap sizes were computed using the general guidelines described in Hydraulic Engineering Circular 18 (Richardson and others, 1995). Total scour at a highway crossing is comprised of three components: 1) long-term streambed degradation; 2) contraction scour (due to accelerated flow caused by a reduction in flow area at a bridge) and; 3 ) local scour (caused by accelerated flow around piers and abutments). Total scour is the sum of the three components. Equations are available to compute depths for contraction and local scour and a summary of the results of these computations follows.

Contraction scour for all modelled flows ranged from 0.0 to $1.4 \mathrm{ft}$. The worst-case contraction scour occurred at the incipient roadway-overtopping discharge, which was less than the 100-year discharge. Abutment scour ranged from 2.2 to $7.4 \mathrm{ft}$ on the left and from 14.7 to $17.7 \mathrm{ft}$ on the right. The worst-case abutment scour occurred at the incipient roadway-overtopping discharge for the left and at the 500-year discharge for the right. Additional information on scour depths and depths to armoring are included in the section titled "Scour Results". Scoured-streambed elevations, based on the calculated scour depths, are presented in tables 1 and 2. A cross-section of the scour computed at the bridge is presented in figure 8. Scour depths were calculated assuming an infinite depth of erosive material and a homogeneous particle-size distribution.

It is generally accepted that the Froehlich equation (abutment scour) gives "excessively conservative estimates of scour depths" (Richardson and others, 1995, p. 47). Usually, computed scour depths are evaluated in combination with other information including (but not limited to) historical performance during flood events, the geomorphic stability assessment, existing scour protection measures, and the results of the hydraulic analyses. Therefore, scour depths adopted by VTAOT may differ from the computed values documented herein. 


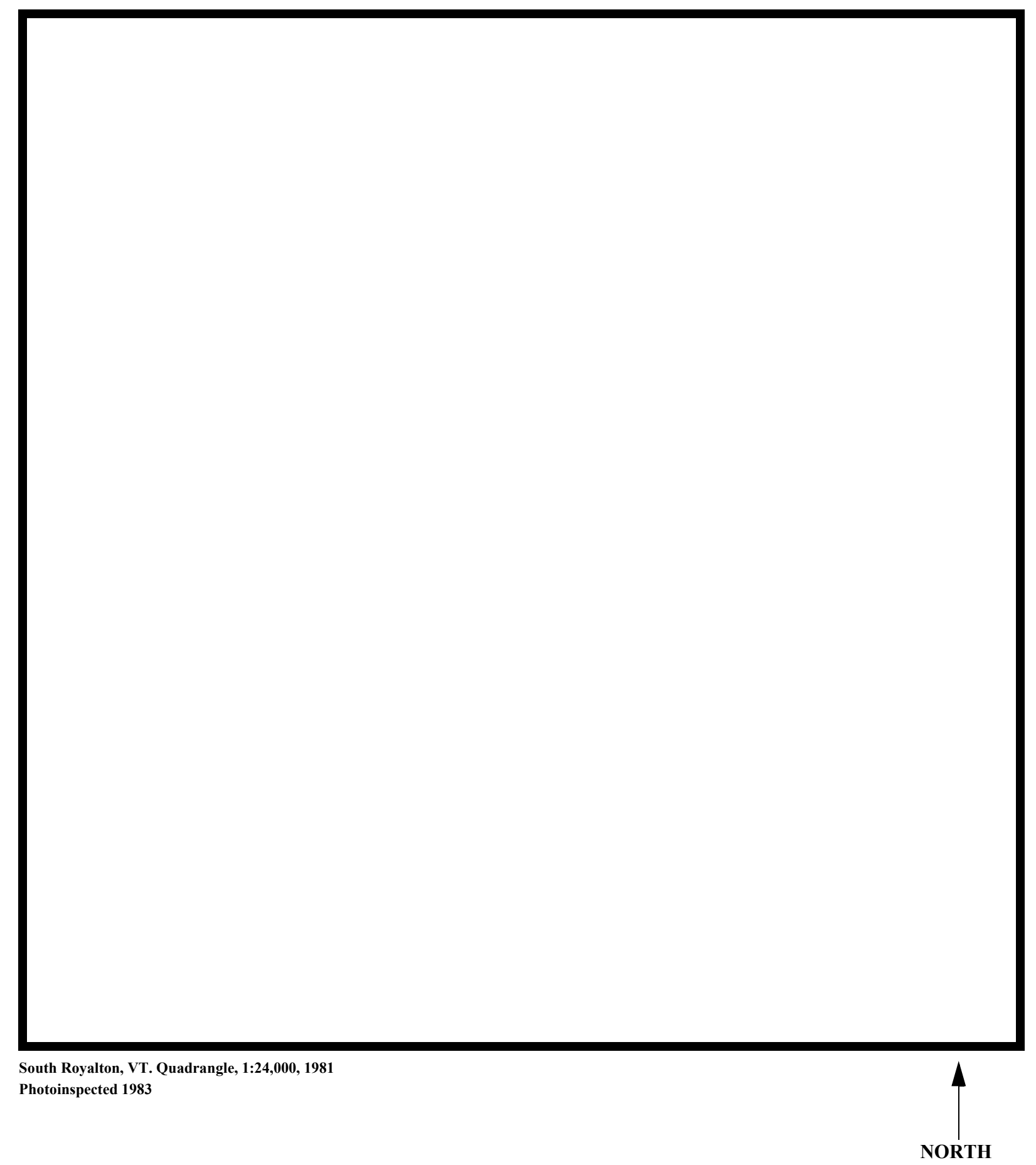

Figure 1. Location of study area on USGS 1:24,000 scale map. 
Figure 2. Location of study area on Vermont Agency of Transportation town highway map. 

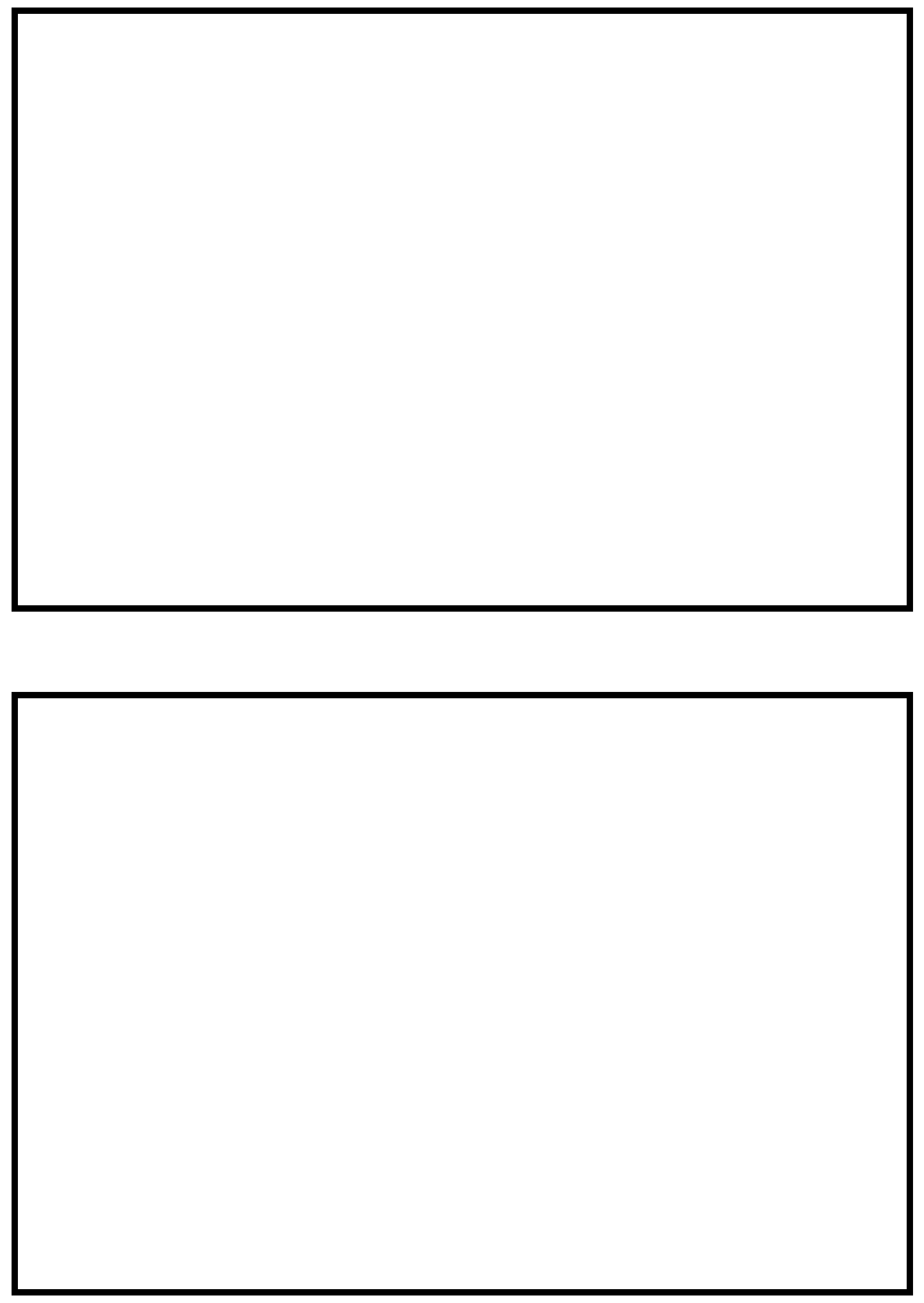

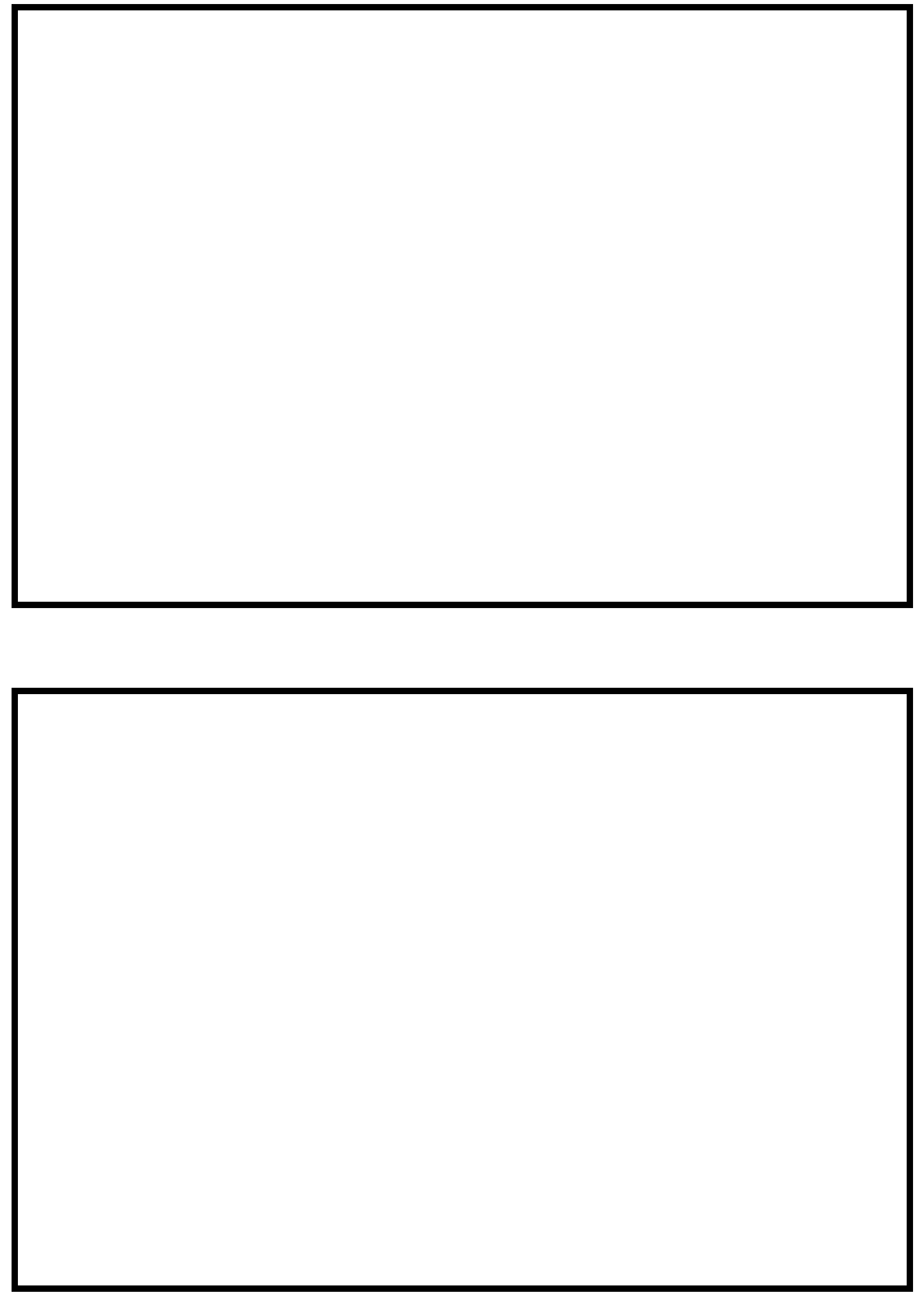


\section{LEVEL II SUMMARY}

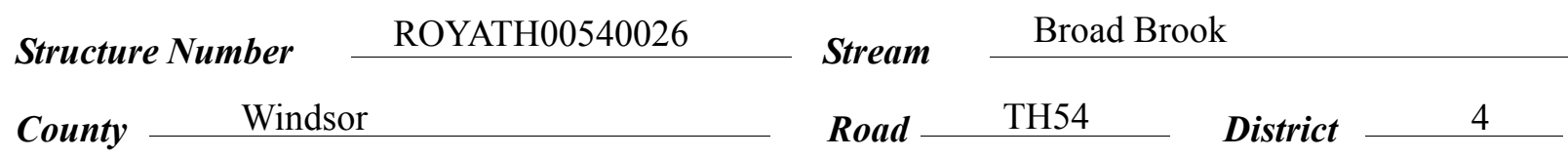

\section{Description of Bridge}

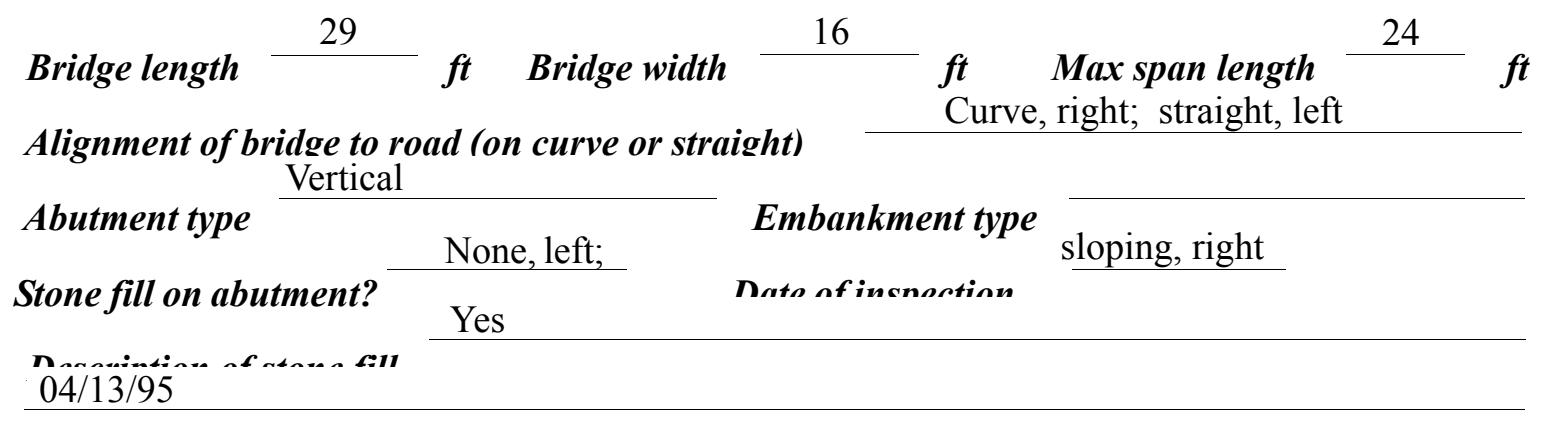

Type-2, along the upstream end of the upstream left wingwall, along the baselength of the

downstream left wingwall, and at the upstream end of

the right abutment.

On the left, the abutment is concrete faced laid-up stone with concrete wingwalls. On the right,

Is bridge skewed to flood flow according to $\mathrm{nt}$ is 'survey? $\quad$ the $\quad$ abutme

laid-up stone...There is a one foot deep scour hole at the downstream end of the right abutment.

Yes

Debris accumulation on bridge at time of Level I or Level II site visit:

\section{Date af insnortion
20 \\ Percent Of nhomnol blocked inortzontatly}

a mild channel bend in
Percent $\sigma_{\text {There is }}^{\text {and }}$ el
blocked verticatty the

Level I upstream reach. The scour hole has developed in the location where

Level II the bend impacts the right abutment.

Potential for debris

$04 / 13 / 95$

Doscriho anv fonturos noar ar at tho hridoo that mav, affort flow (includo ahsorvation dato) 0

0 


\section{Description of the Geomorphic Setting}

General topography The channel is located within a moderate relief valley with a narrow flood plain on the left and steep valley walls on both sides.

Geomorphic conditions at bridge site: downstream (DS), upstream (US)

Date of inspection $\quad 04 / 13 / 95$

DS left: $\quad$ Slightly irregular, narrow flood plain

DS right: $\quad$ Steep valley wall

US left: $\quad$ Steep channel bank to a narrow flood plain

US right: $\quad$ Steep valley wall

\section{Description of the Channel}

\begin{tabular}{lllll} 
Average top width & 37 & Average depth & \multicolumn{4}{c}{ Gravel/Sand }
\end{tabular}

Predominant bed material Bank material Sinuous but stable

with semi-allúvial channel boundaries.

$04 / 13 / 95$

Vegetative co ${ }^{1}$ Some trees and brush with short grass on the overbank

DS left: $\quad$ Trees and brush

DS right: $\quad$ Some trees and brush with short grass on the overbank

US left: $\quad$ Trees and brush

US right: $\quad$ Yes

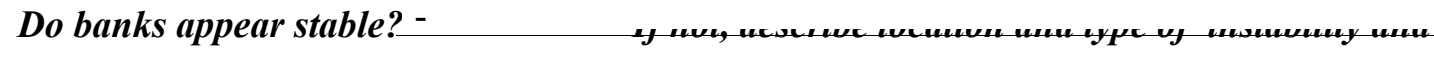

date of observatton.

None as of $04 / 13 / 95$.

Describe any obstructions in channel and date of observation. 


\title{
Hydrology
}

Drainage area $\frac{11.9}{m^{2}}{ }^{2}$

Percentage of drainage area in physiographic provinces: (approximate)

Physiographic province/section New England/New England Upland
Percent of drainage area 100

\begin{abstract}
Is drainage area considered rural or urban? Rural Describe any significant urbanization:
\end{abstract}

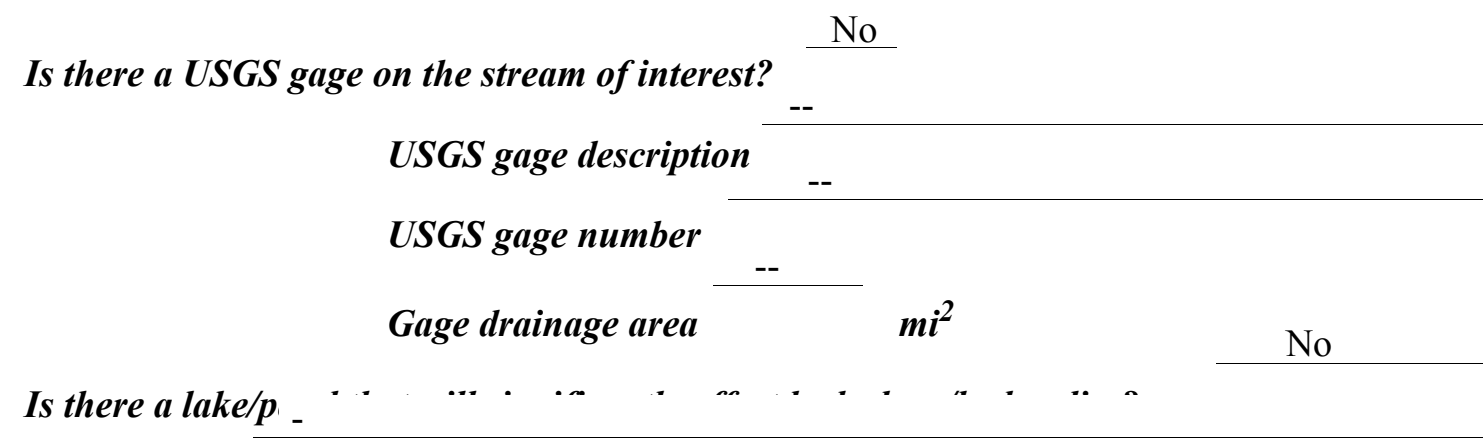

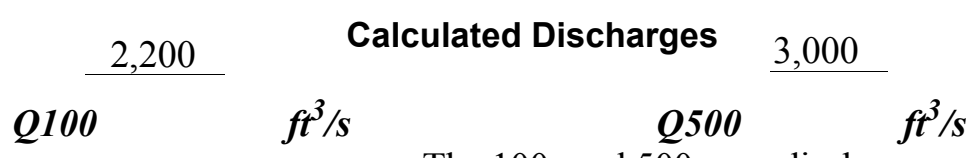

The 100- and 500-year discharges are based on the

median yalue defined by flood frequency curves which were developed from several empirical methods and extended to the 500-year event. (Benson, 1962; Johnson and Tasker, 1974; FHWA, 1983; Potter, 1957a\&b; Talbot, 1887) 


\section{Description of the Water-Surface Profile Model (WSPRO) Analysis}

Datum for WSPRO analysis (USGS survey, sea level, VTAOT plans)

USGS survey

Datum tie between USGS survey and VTAOT plans

None

Description of reference marks used to determine USGS datum. $\quad$ RM1 is a chiseled X on

top of the upstream end of the upstream left wingwall (elev. $499.33 \mathrm{ft}$, arbitrary survey datum).

$\mathrm{RM} 2$ is a nail in a one foot diameter ash tree located $10 \mathrm{ft}$. east of the bridge along the road on

the downstream right bank (elev. $505.82 \mathrm{ft}$, arbitrary survey datum).

\section{Cross-Sections Used in WSPRO Analysis}

\begin{tabular}{|c|c|c|c|}
\hline${ }^{1}$ Cross-section & $\begin{array}{c}\text { Section } \\
\text { Reference } \\
\text { Distance } \\
\text { (SRD) in feet }\end{array}$ & $\begin{array}{c}{ }^{2} \text { Cross-section } \\
\text { development }\end{array}$ & Comments \\
\hline EXITX & -29 & 1 & Exit section \\
\hline FULLV & 0 & 2 & $\begin{array}{l}\text { Downstream Full-valley } \\
\text { section (Templated from } \\
\text { EXITX) }\end{array}$ \\
\hline BRIDG & 0 & 1 & Bridge section \\
\hline RDWAY & 10 & 1 & Road Grade section \\
\hline APPRO & 44 & 2 & $\begin{array}{l}\text { Modelled Approach sec- } \\
\text { tion (Templated from } \\
\text { APTEM) }\end{array}$ \\
\hline APTEM & 39 & 1 & $\begin{array}{l}\text { Approach section as sur- } \\
\text { veyed (Used as a tem- } \\
\text { plate) }\end{array}$ \\
\hline
\end{tabular}

${ }^{1}$ For location of cross-sections see plan-view sketch included with Level I field form, Appendix E.

For more detail on how cross-sections were developed see WSPRO input file. 


\section{Data and Assumptions Used in WSPRO Model}

Hydraulic analyses of the reach were done by use of the Federal Highway Administration's WSPRO step-backwater computer program (Shearman and others, 1986, and Shearman, 1990). The analyses reported herein reflect conditions existing at the site at the time of the study. Furthermore, in the development of the model it was necessary to assume no accumulation of debris or ice at the site. Results of the hydraulic model are presented in the Bridge Hydraulic Summary, Appendix B, and figure 7.

Channel roughness factors (Manning's " $n$ ") used in the hydraulic model were estimated using field inspections at each cross section following the general guidelines described by Arcement and Schneider (1989). Final adjustments to the values were made during the modelling of the reach. Channel " $n$ " values for the reach ranged from 0.040 to 0.055 , and overbank " $n$ " values ranged from 0.045 to 0.060 .

Normal depth at the exit section (EXITX) was assumed as the starting water surface. This depth was computed by use of the slope-conveyance method outlined in the user's manual for WSPRO (Shearman, 1990). The slope used was $0.0102 \mathrm{ft} / \mathrm{ft}$ which was estimated from points surveyed downstream of the bridge.

The surveyed approach section (APTEM) was moved along the approach channel slope $(0.0028 \mathrm{ft} / \mathrm{ft})$ to establish the modelled approach section (APPRO), one bridge length upstream of the upstream face as recommended by Shearman and others (1986). This location also provides a consistent method for determining scour variables.

For the incipient-overtopping discharge, WSPRO assumes critical depth at the bridge section. A supercritical model was developed for this discharge. After analyzing both the

supercritical and subcritical profiles for the incipient-overtopping discharge, it can be determined that the water surface profile does pass through critical depth within the bridge opening. Thus, the assumptions of critical depth at the bridge are satisfactory solutions. 


\section{Bridge Hydraulics Summary}

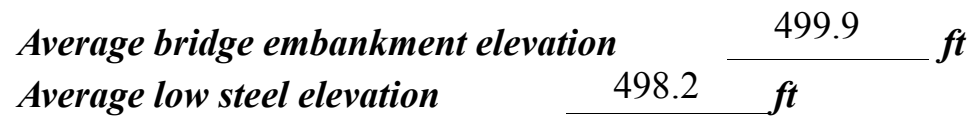

$$
\text { 100-year discharge } \quad 2,200 \quad \mathrm{ft}^{3} / \mathrm{s}
$$

Water-surface elevation in bridge opening $\quad 498.4 \quad f t$

Road overtopping? ___ Yes Discharge over road __ $657 \quad \mathrm{ft}^{3} / \mathrm{s}$

Area of flow in bridge opening $\quad 183 \quad \mathrm{ft}^{2}$

Average velocity in bridge opening $\quad 8.4 \quad \mathrm{ft} / \mathrm{s}$

$\begin{array}{lll}\text { Maximum WSPRO tube velocity at bridge } & 10.2 \mathrm{ft} / \mathrm{s}\end{array}$

Water-surface elevation at Approach section with bridge 499.8

Water-surface elevation at Approach section without bridge $\quad 497.1$

Amount of backwater caused by bridge

$2.7 \quad i$

500-year discharge $\quad 3,000 \quad \mathrm{ft}^{3} / \mathrm{s}$

Water-surface elevation in bridge opening $\quad 498.2 \mathrm{ft}$

Road overtopping? ___ Yes Discharge over road __ $1253 \quad \mathrm{ft}^{3} / \mathrm{s}$

Area of flow in bridge opening $\quad 183 \quad \mathrm{ft}^{2}$

Average velocity in bridge opening $\quad 9.3 \mathrm{ft} / \mathrm{s}$

Maximum WSPRO tube velocity at bridge 12.9 /s

Water-surface elevation at Approach section with bridge 500.4

Water-surface elevation at Approach section without bridge $\quad 498.3$

Amount of backwater caused by bridge $\quad 2.1$.t

Incipient overtopping discharge $\quad 1,550 \mathrm{ft}^{3} / \mathrm{s}$

Water-surface elevation in bridge opening $495.5 \quad t$

Area of flow in bridge opening $\quad 120 \quad \mathrm{ft}^{2}$

Average velocity in bridge opening $\quad 12.9 \quad \mathrm{ft} / \mathrm{s}$

Maximum WSPRO tube velocity at bridge $16.0 \mathrm{ft} / \mathrm{s}$

Water-surface elevation at Approach section with bridge

Water-surface elevation at Approach section without bridge

498.4

Amount of backwater caused by bridge $\quad 2.2$, $t$

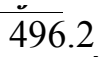




\section{Scour Analysis Summary}

\section{Special Conditions or Assumptions Made in Scour Analysis}

Scour depths were computed using the general guidelines described in Hydraulic Engineering Circular 18 (Richardson and others, 1995). Scour depths were calculated assuming an infinite depth of erosive material and a homogeneous particle-size distribution. The results of the scour analysis are presented in tables 1 and 2 and a graph of the scour depths is presented in figure 8 .

Contraction scour for the incipient roadway-overtopping discharge was computed by use of the Laursen clear-water contraction scour equation (Richardson and others, 1995, p. 32 , equation 20). At this site, the 100-year and 500-year discharges resulted in unsubmerged orifice flow. Contraction scour at bridges with orifice flow is best estimated by use of the Chang pressure-flow scour equation (oral communication, J. Sterling Jones, October 4, 1996). Thus, contraction scour for these discharges was computed by use of the Chang equation (Richardson and others, 1995, p. 145-146). The streambed armoring depths computed suggest that armoring will not limit the depth of contraction scour.

For the discharges resulting in orifice flow, estimates of contraction scour were also computed by use of the Laursen clear-water contraction scour equation and the Umbrell pressure-flow equation (Richardson and others, 1995, p. 144) and presented in Appendix F. Furthermore, for those discharges resulting in unsubmerged orifice flow, contraction scour was computed by substituting estimates for the depth of flow at the downstream bridge face into the contraction scour equations. Results with respect to these substitutions are provided in Appendix F.

Scour at the right abutment and at the left abutment for the incipient roadovertopping discharge was computed by use of the Froehlich equation (Richardson and others, 1995, p. 48, equation 28). Variables for the Froehlich equation include the Froude number of the flow approaching the embankments, the length of the embankment blocking flow, and the depth of flow approaching the embankment less any roadway overtopping.

Scour at the left abutment for the 100-year and 500-year discharges was computed by use of the HIRE equation (Richardson and others, 1995, p. 49, equation 29) because the HIRE equation is recommended when the length to depth ratio of the embankment blocking flow exceeds 25 . The incipient road-overtopping discharge, which is less than the 100-year discharge, does not flow into the flood plain on the left overbank, and scour was computed by use of the Froehlich equation. The variables used by the HIRE abutment-scour equation are defined the same as those defined for the Froehlich abutment-scour equation. 


\section{Scour Results}
100-yr discharge 500-yr discharge
Incipient overtopping (Scour depths in feet)

Contraction scour:

Main channel

Live-bed scour

Clear-water scour

Depth to armoring

Left overbank

Right overbank

\begin{tabular}{cccc}
-- & -- & -- \\
6.0 & & 0.1 & 1.4 \\
$6.5^{-}$ & & $5.6^{-}$ & $\mathrm{N} / \mathrm{A}^{-}$ \\
$--^{-}$ & $--^{-}$ & $--^{-}$ \\
--- & -- & - \\
\hline
\end{tabular}

Local scour:

Abutment scour

2.2

2.9

7.4

Left abutment

15.8

17.7-

14.7-

\section{Right abutment}

Pier scour

Pier 1

Pier 2

Pier 3

Abutments:

\section{Left abutment}

Right abutment

Piers:

Pier 1

Pier 2

\section{Riprap Sizing}

Incipient overtopping 100-yr discharge 500-yrdischarge discharge

2.1

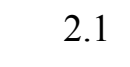

$--$

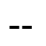

$--$ ( $D_{50}$ in feet)

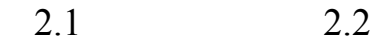

2.1

2.2

$--$

$-$

$---$ 


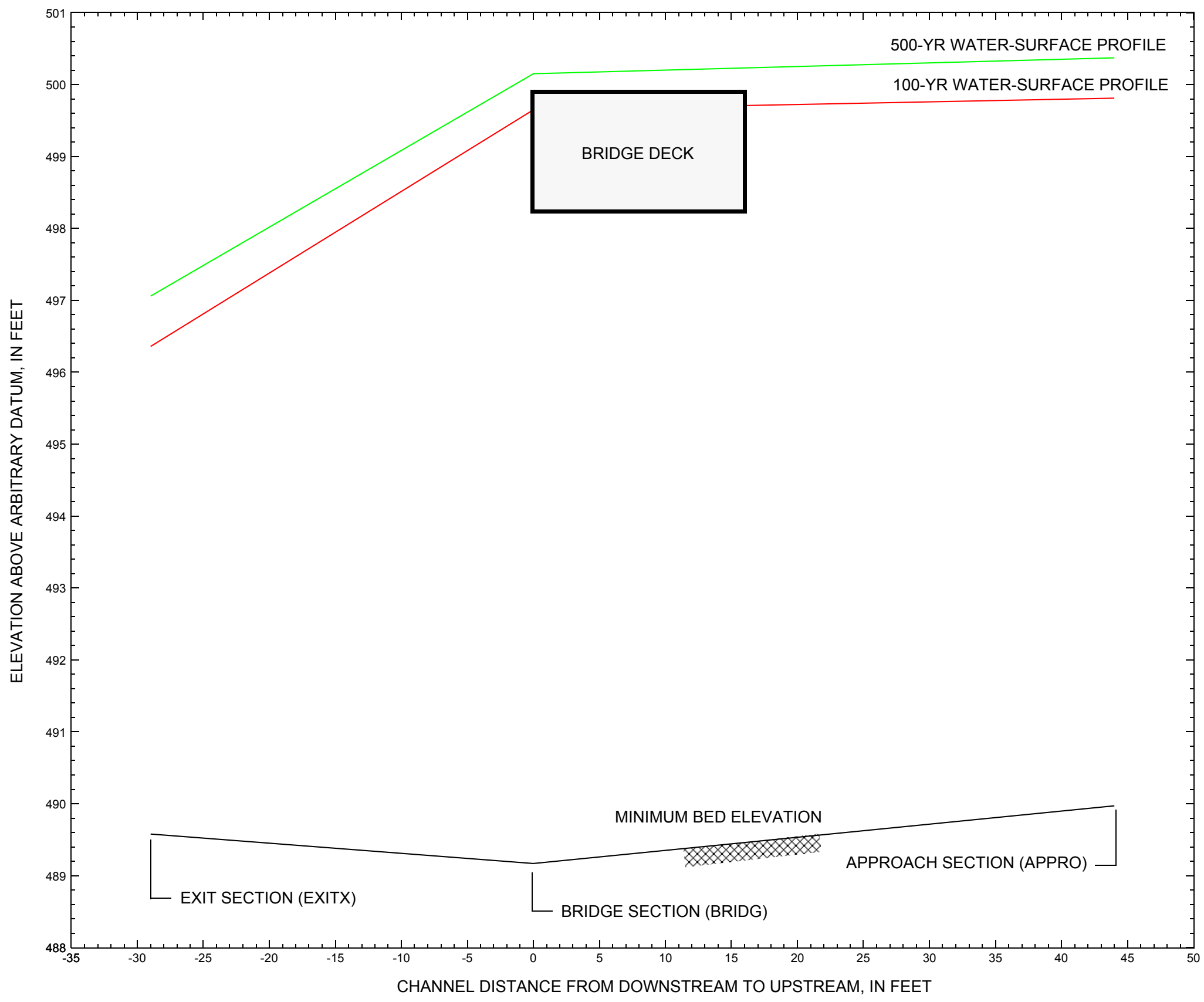

Figure 7. Water-surface profiles for the 100- and 500-yr discharges at structure ROYATH00540026 on Town Highway 54, crossing Broad Brook, Royalton, Vermont. 


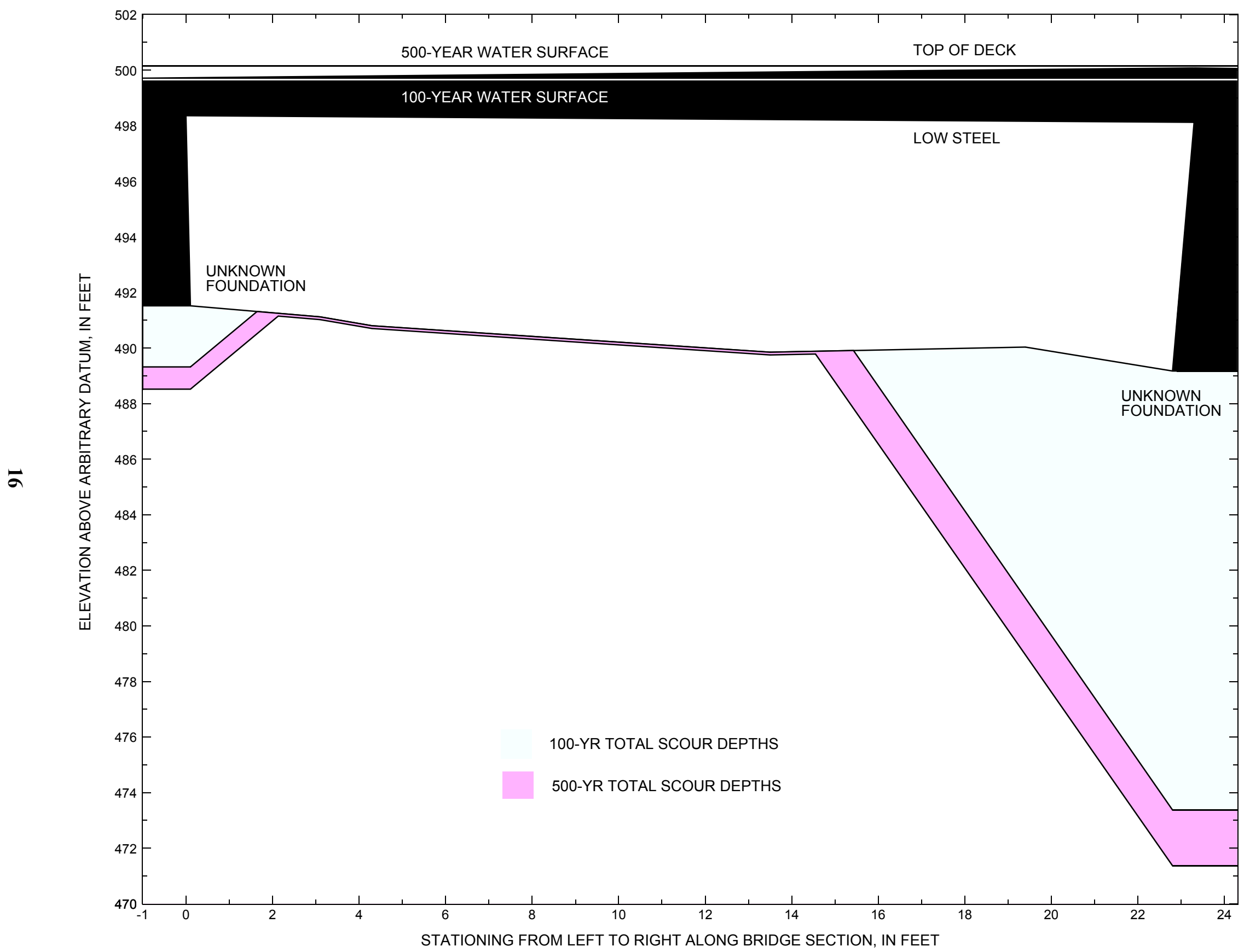

Figure 8. Scour elevations for the 100-yr and 500-yr discharges at structure ROYATH00540026 on Town Highway 54, crossing Broad Brook, Royalton, Vermont. 
Table 1. Remaining footing/pile depth at abutments for the 100-year discharge at structure ROYATH00540026 on Town Highway 54, crossing Broad Brook, Royalton, Vermont.

[VTAOT, Vermont Agency of Transportation; --, no data]

\begin{tabular}{|c|c|c|c|c|c|c|c|c|c|c|c|}
\hline Description & Station $^{1}$ & $\begin{array}{l}\text { VTAOT } \\
\text { minimum } \\
\text { low-chord } \\
\text { elevation } \\
\text { (feet) }\end{array}$ & $\begin{array}{l}\text { Surveyed } \\
\text { minimum } \\
\text { low-chord } \\
\text { elevation } \\
\text { (feet) }\end{array}$ & $\begin{array}{l}\text { Bottom of } \\
\text { footing } \\
\text { elevation }{ }^{2} \\
\text { (feet) }\end{array}$ & $\begin{array}{l}\text { Channel } \\
\text { elevation at } \\
\text { abutment/ } \\
\text { pier }^{2} \\
\text { (feet) }\end{array}$ & $\begin{array}{l}\text { Contraction } \\
\text { scour depth } \\
\text { (feet) }\end{array}$ & $\begin{array}{l}\text { Abutment } \\
\text { scour } \\
\text { depth } \\
\text { (feet) }\end{array}$ & $\begin{array}{l}\text { Pier } \\
\text { scour } \\
\text { depth } \\
\text { (feet) }\end{array}$ & $\begin{array}{l}\text { Depth of } \\
\text { total scour } \\
\text { (feet) }\end{array}$ & $\begin{array}{c}\text { Elevation of } \\
\text { scour }^{2} \\
\text { (feet) }\end{array}$ & $\begin{array}{c}\text { Remaining } \\
\text { footing/pile } \\
\text { depth } \\
\text { (feet) }\end{array}$ \\
\hline \multicolumn{12}{|c|}{100 -yr. discharge is 2,200 cubic-feet per second } \\
\hline Left abutment & 0.1 & -- & 498.4 & -- & 491.5 & 0.0 & 2.2 & -- & 2.2 & 489.3 & -- \\
\hline Right abutment & 22.8 & -- & 498.1 & -- & 489.2 & 0.0 & 15.8 & -- & 15.8 & 473.4 & -- \\
\hline
\end{tabular}

1.Measured along the face of the most constricting side of the bridge.

2.Arbitrary datum for this study.

Table 2. Remaining footing/pile depth at abutments for the 500-year discharge at structure ROYATH00540026 on Town Highway 54, crossing Broad Brook, Royalton, Vermont.

[VTAOT, Vermont Agency of Transportation; --, no data]

\begin{tabular}{|c|c|c|c|c|c|c|c|c|c|c|c|}
\hline Description & Station $^{1}$ & $\begin{array}{l}\text { VTAOT } \\
\text { minimum } \\
\text { low-chord } \\
\text { elevation } \\
\text { (feet) }\end{array}$ & $\begin{array}{c}\text { Surveyed } \\
\text { minimum } \\
\text { low-chord } \\
\text { elevation } \\
\text { (feet) }\end{array}$ & $\begin{array}{l}\text { Bottom of } \\
\text { footing } \\
\text { elevation } \\
\text { (feet) }\end{array}$ & $\begin{array}{c}\text { Channel } \\
\text { elevation at } \\
\text { abutment/ } \\
\text { pier }^{2} \\
\text { (feet) }\end{array}$ & $\begin{array}{l}\text { Contraction } \\
\text { scour depth } \\
\text { (feet) }\end{array}$ & $\begin{array}{l}\text { Abutment } \\
\text { scour } \\
\text { depth } \\
\text { (feet) }\end{array}$ & $\begin{array}{l}\text { Pier } \\
\text { scour } \\
\text { depth } \\
\text { (feet) }\end{array}$ & $\begin{array}{l}\text { Depth of } \\
\text { total scour } \\
\text { (feet) }\end{array}$ & $\begin{array}{c}\text { Elevation of } \\
\text { scour }^{2} \\
\text { (feet) }\end{array}$ & $\begin{array}{c}\text { Remaining } \\
\text { footing/pile } \\
\text { depth } \\
\text { (feet) }\end{array}$ \\
\hline \multicolumn{12}{|c|}{500 -yr. discharge is 3,000 cubic-feet per second } \\
\hline Left abutment & 0.1 & -- & 498.4 & -- & 491.5 & 0.1 & 2.9 & -- & 3.0 & 488.5 & -- \\
\hline Right abutment & 22.8 & -- & 498.1 & -- & 489.2 & 0.1 & 17.7 & -- & 17.8 & 471.4 & -- \\
\hline
\end{tabular}

1.Measured along the face of the most constricting side of the bridge.

2.Arbitrary datum for this study. 


\section{SELECTED REFERENCES}

Arcement, G.J., Jr., and Schneider, V.R., 1989, Guide for selecting Manning's roughness coefficients for natural channels and flood plains: U.S. Geological Survey Water-Supply Paper 2339, 38 p.

Barnes, H.H., Jr., 1967, Roughness characteristics of natural channels: U.S. Geological Survey Water-Supply Paper 1849,213 p.

Benson, M. A., 1962, Factors Influencing the Occurrence of Floods in a Humid Region of Diverse Terrain: U.S. Geological Survey WaterSupply Paper 1580-B, 64 p.

Brown, S.A. and Clyde, E.S., 1989, Design of riprap revetment: Federal Highway Administration Hydraulic Engineering Circular No. 11, Publication FHWA-IP-89-016, 156 p.

Federal Highway Administration, 1983, Runoff estimates for small watersheds and development of sound design: Federal Highway Administration Report FHWA-RD-77-158.

Federal Highway Administration, 1993, Stream Stability and Scour at Highway Bridges: Participant Workbook: Federal Highway Administration Report FHWA-HI-91-011.

Froehlich, D.C., 1989, Local scour at bridge abutments in Ports, M.A., ed., Hydraulic Engineering--Proceedings of the 1989 National Conference on Hydraulic Engineering: New York, American Society of Civil Engineers, p. 13-18.

Hayes, D.C.,1993, Site selection and collection of bridge-scour data in Delaware, Maryland, and Virginia: U.S. Geological Survey WaterResources Investigation Report 93-4017, 23 p.

Interagency Advisory Committee on Water Data, 1982, Guidelines for determining flood flow frequency: U.S. Geological Survey, Bulletin 17B of the Hydrology Subcommittee, 190 p.

Johnson, C.G. and Tasker, G.D.,1974, Progress report on flood magnitude and frequency of Vermont streams: U.S. Geological Survey OpenFile Report 74-130, 37 p.

Lagasse, P.F., Schall, J.D., Johnson, F., Richardson, E.V., Chang, F., 1995, Stream Stability at Highway Structures: Federal Highway Administration Hydraulic Engineering Circular No. 20, Publication FHWA-IP-90-014, 144 p.

Laursen, E.M., 1960, Scour at bridge crossings: Journal of the Hydraulics Division, American Society of Civil Engineers, v. 86, no. HY2, p. 39-53.

Potter, W. D., 1957a, Peak rates of runoff in the Adirondack, White Mountains, and Maine woods area, Bureau of Public Roads

Potter, W. D., 1957b, Peak rates of runoff in the New England Hill and Lowland area, Bureau of Public Roads

Richardson, E.V. and Davis, S.R., 1995, Evaluating scour at bridges: Federal Highway Administration Hydraulic Engineering Circular No. 18, Publication FHWA-IP-90-017, 204 p.

Richardson, E.V., Simons, D.B., and Julien, P.Y., 1990, Highways in the river environment: Federal Highway Administration Publication FHWA-HI-90-016.

Ritter, D.F., 1984, Process Geomorphology: W.C. Brown Co., Debuque, Iowa, 603 p.

Shearman, J.O., 1990, User's manual for WSPRO--a computer model for water surface profile computations: Federal Highway Administration Publication FHWA-IP-89-027, 187 p.

Shearman, J.O., Kirby, W.H., Schneider, V.R., and Flippo, H.N., 1986, Bridge waterways analysis model; research report: Federal Highway Administration Publication FHWA-RD-86-108, 112 p.

Talbot, A.N., 1887, The determination of water-way for bridges and culverts.

U.S. Department of Transportation, 1993, Stream stability and scour at highway bridges, Participant Workbook: Federal Highway Administration Publication FHWA HI-91-011.

U.S. Geological Survey, 1981, South Royalton, Vermont 7.5 Minute Series quadrangle map: U.S. Geological Survey Topographic Maps, Photoinspected 1983, Scale 1:24,000. 


\section{APPENDIX A: \\ WSPRO INPUT FILE}




\section{WSPRO INPUT FILE}

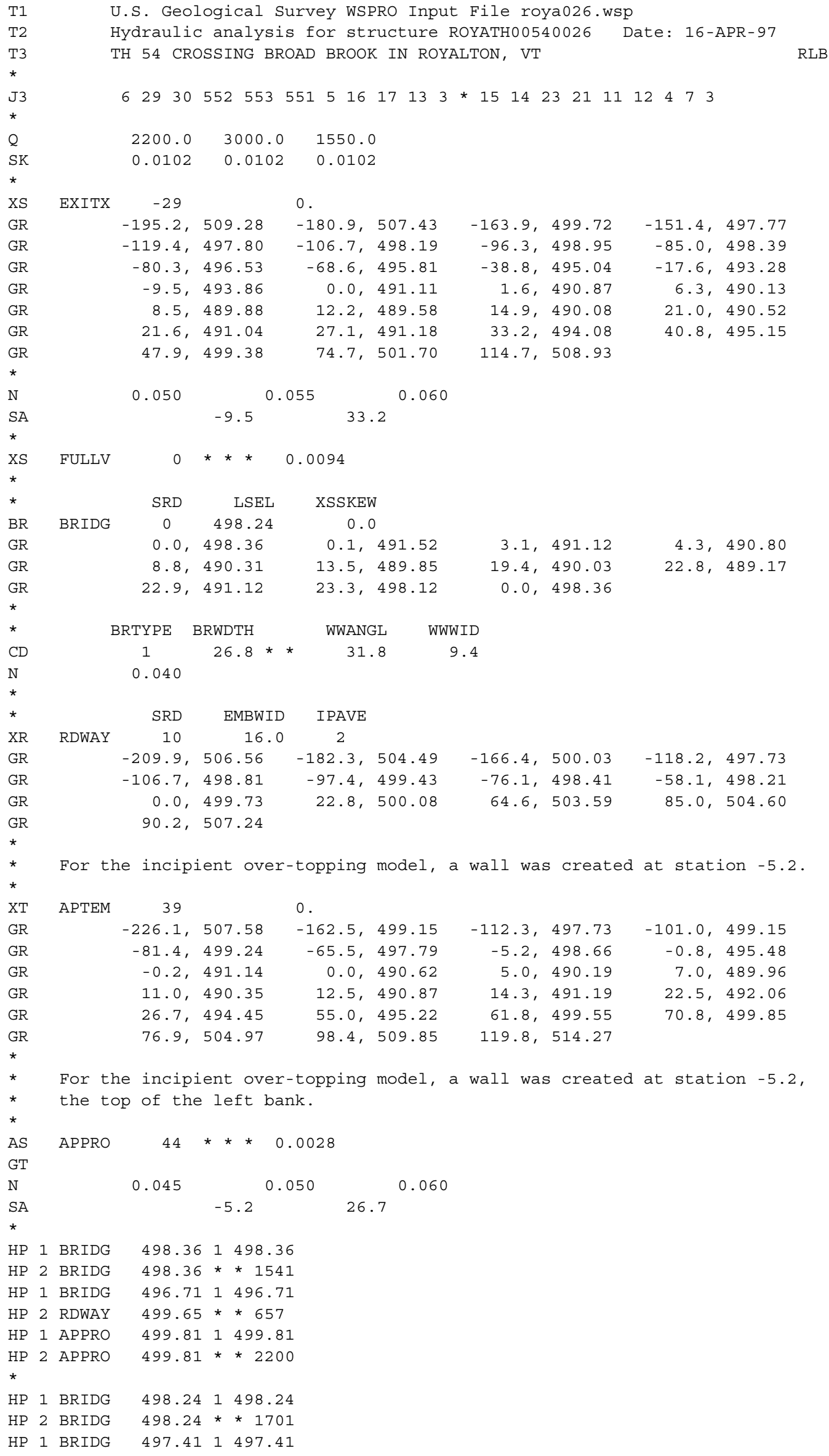




\section{APPENDIX B: \\ WSPRO OUTPUT FILE}




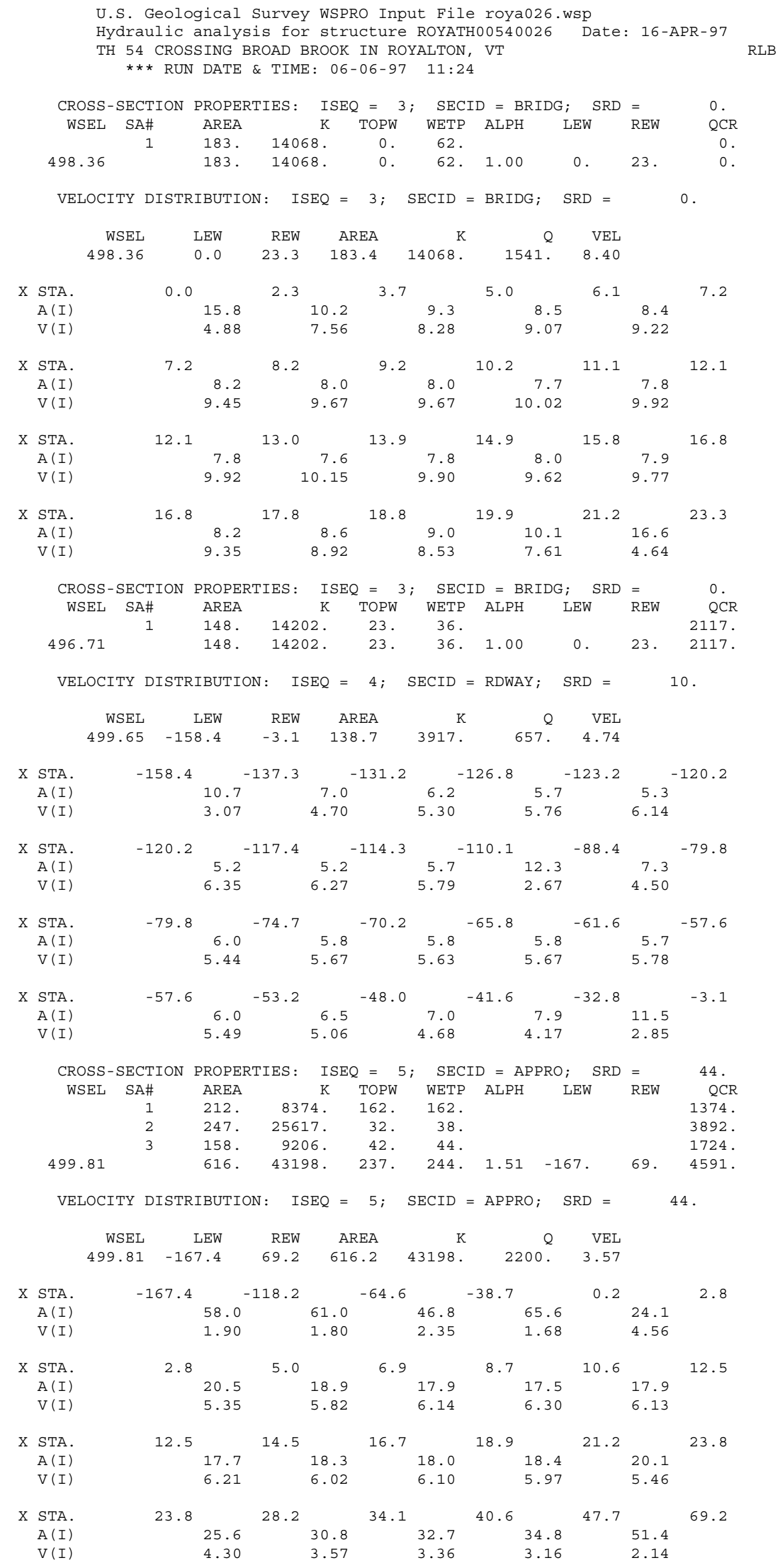


WSPRO OUTPUT FILE (continued)

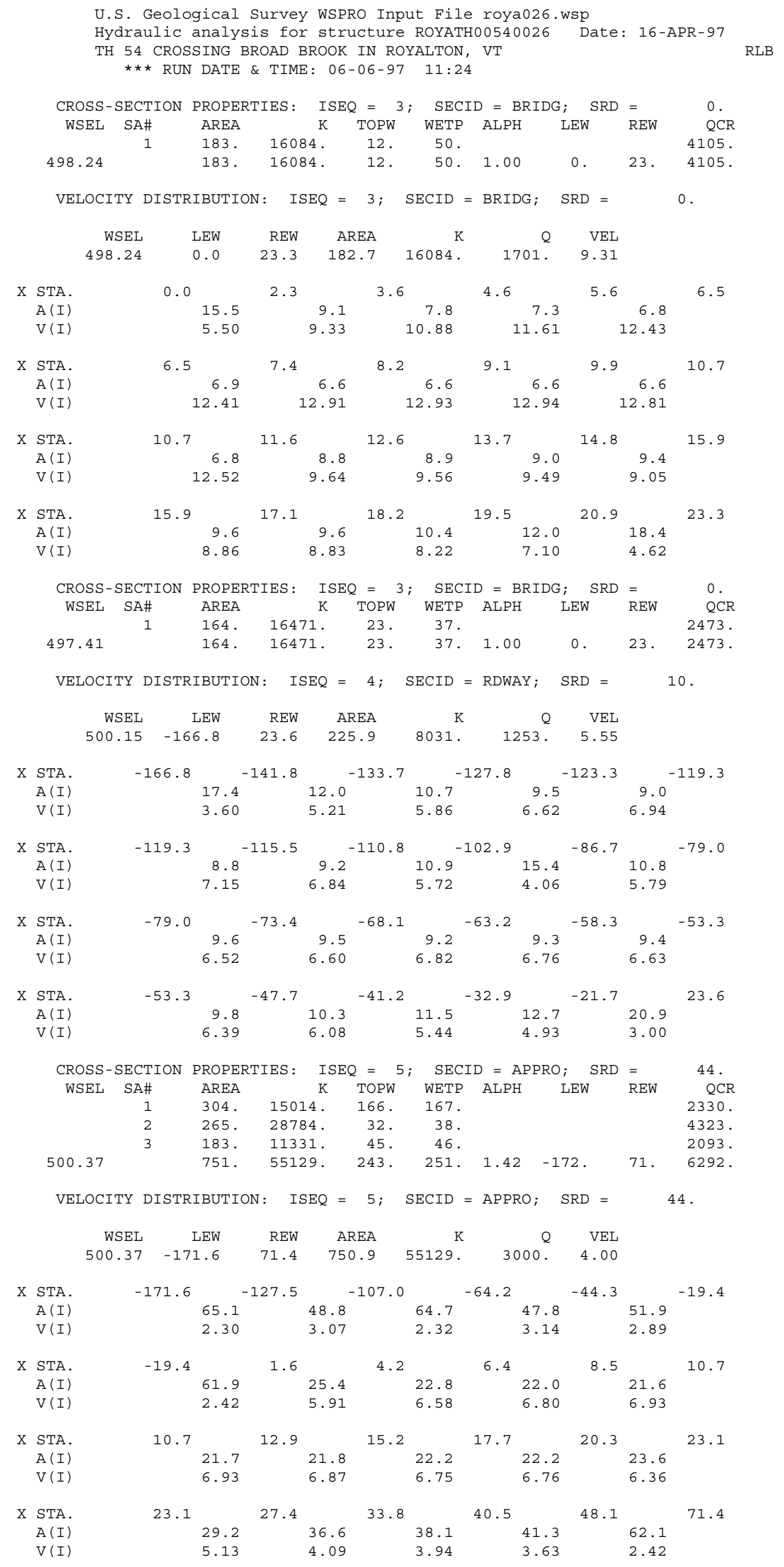


WSPRO OUTPUT FILE (continued)

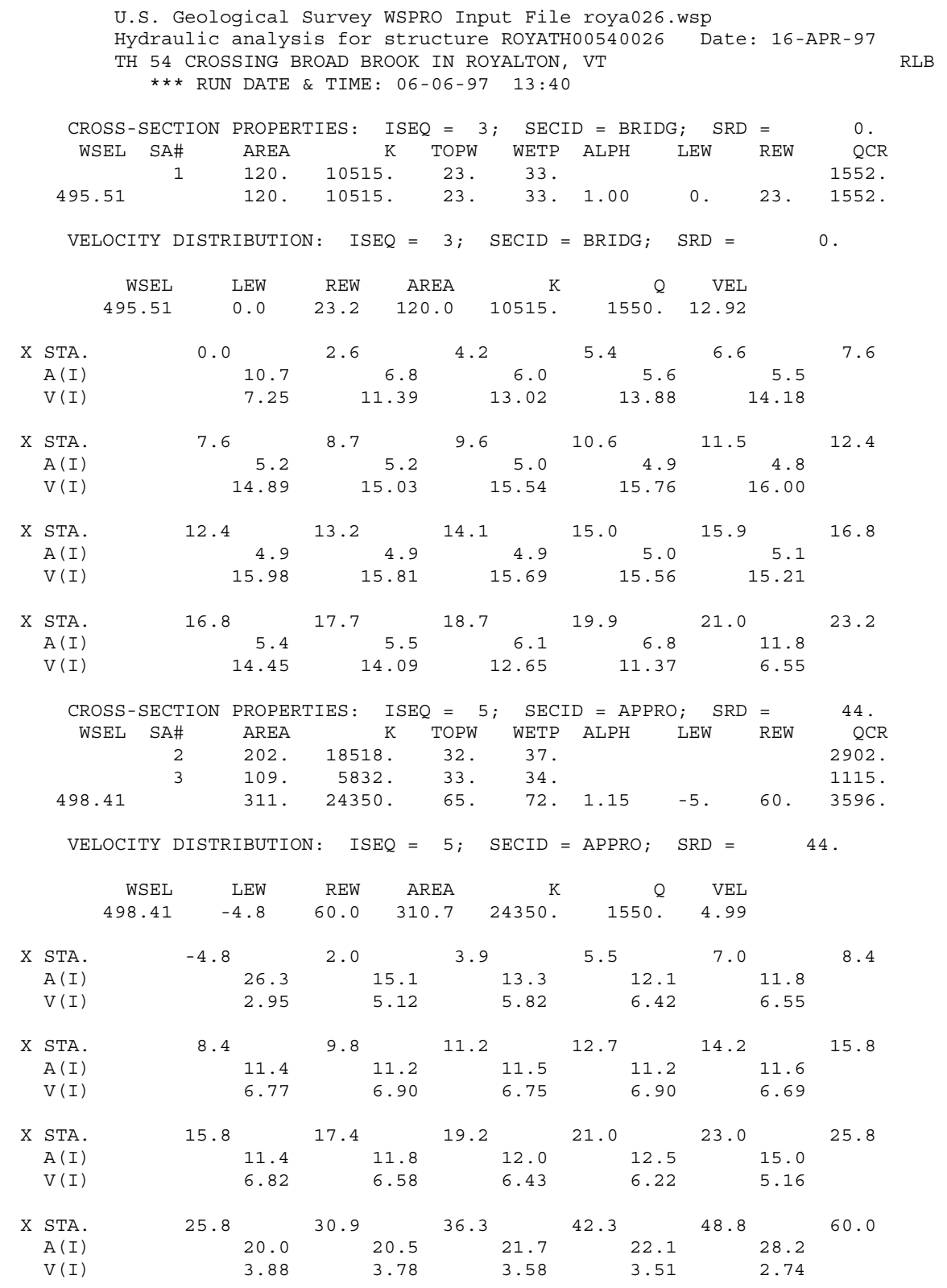


WSPRO OUTPUT FILE (continued)

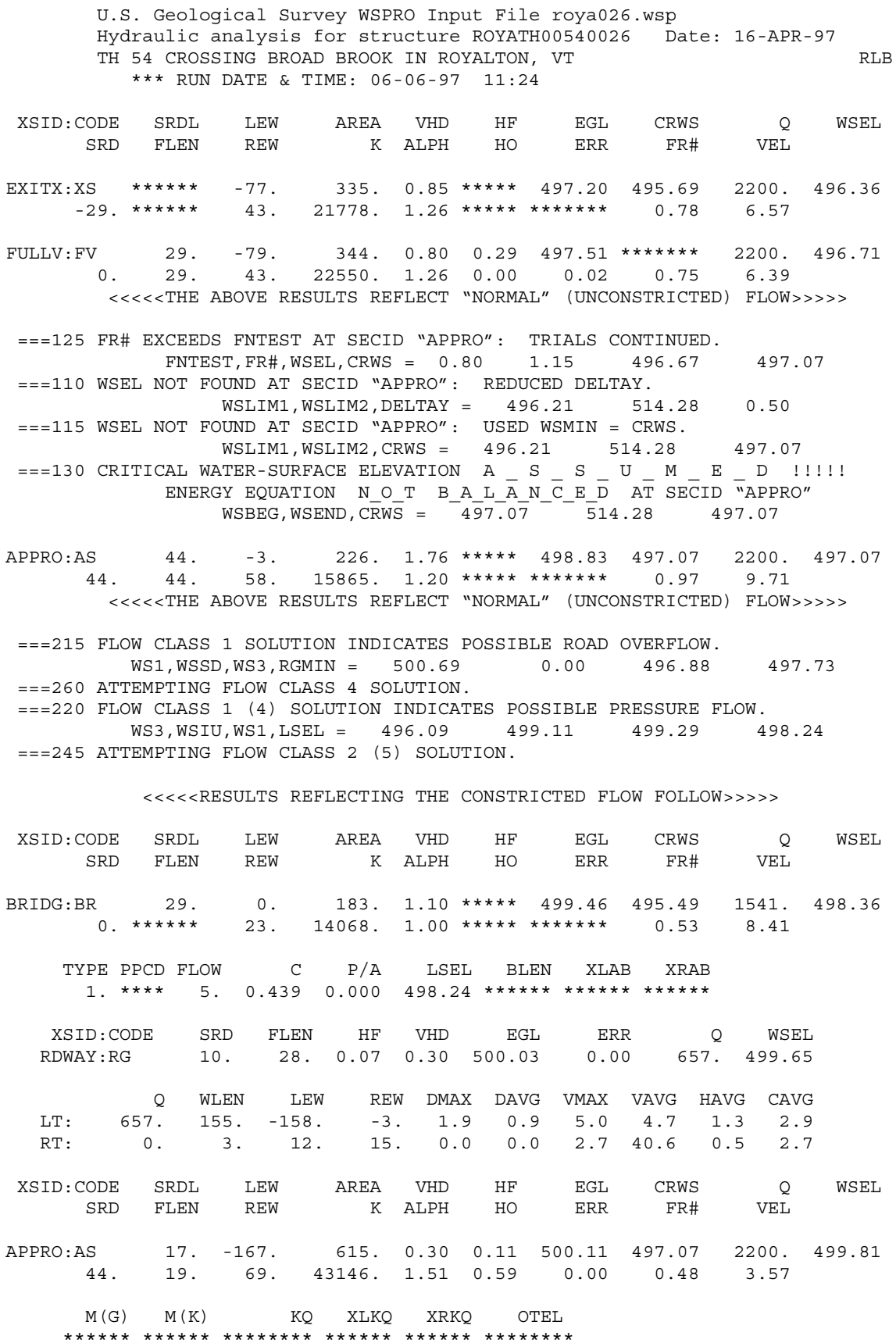

FIRST USER DEFINED TABLE.

\begin{tabular}{|c|c|c|c|c|c|c|c|c|}
\hline XSID : CODE & SRD & LEW & REW & Q & $\mathrm{K}$ & AREA & VEL & WSEL \\
\hline EXITX:XS & -29 & -77 & 43. & 2200 . & 21778 . & 335. & 6.57 & 496.36 \\
\hline FULLV : FV & 0 . & -79 & 43. & 2200 . & 22550 . & 344. & 6.39 & 496.71 \\
\hline BRIDG : BR & 0 . & 0 & 23 & 1541. & 14068 . & 183. & 8.41 & 498.36 \\
\hline RDWAY : RG & 10. & $\star \star \star \star * \star$ & 657. & 657 & 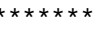 & 0. & 2.00 & 499.65 \\
\hline APPRO: AS & 44. & -167. & 69 & 2200 . & 43146 & 615. & 3.57 & 499.81 \\
\hline XSID : CODE & XLKQ & XRKQ & & & & & & \\
\hline
\end{tabular}

SECOND USER DEFINED TABLE.

$\begin{array}{lcrrrrrrrr}\text { XSID:CODE } & \text { CRWS } & \text { FR\# } & \text { YMIN } & \text { YMAX } & \text { HF } & \text { HO } & \text { VHD } & \text { EGL } & \text { WSEL } \\ \text { EXITX:XS } & 495.69 & 0.78 & 489.58 & 509.28 * * * * * * * * * * * & 0.85 & 497.20 & 496.36 \\ \text { FULLV:FV } & * * * * * * * & 0.75 & 489.85 & 509.55 & 0.29 & 0.00 & 0.80 & 497.51 & 496.71 \\ \text { BRIDG:BR } & 495.49 & 0.53 & 489.17 & 498.36 * * * * * * * * * * * & 1.10 & 499.46 & 498.36 \\ \text { RDWAY:RG } & * * * * * * * * * * * * * * & 497.73 & 507.24 & 0.07 * * * * * & 0.30 & 500.03 & 499.65 \\ \text { APPRO:AS } & 497.07 & 0.48 & 489.97 & 514.28 & 0.11 & 0.59 & 0.30 & 500.11 & 499.81\end{array}$


WSPRO OUTPUT FILE (continued)

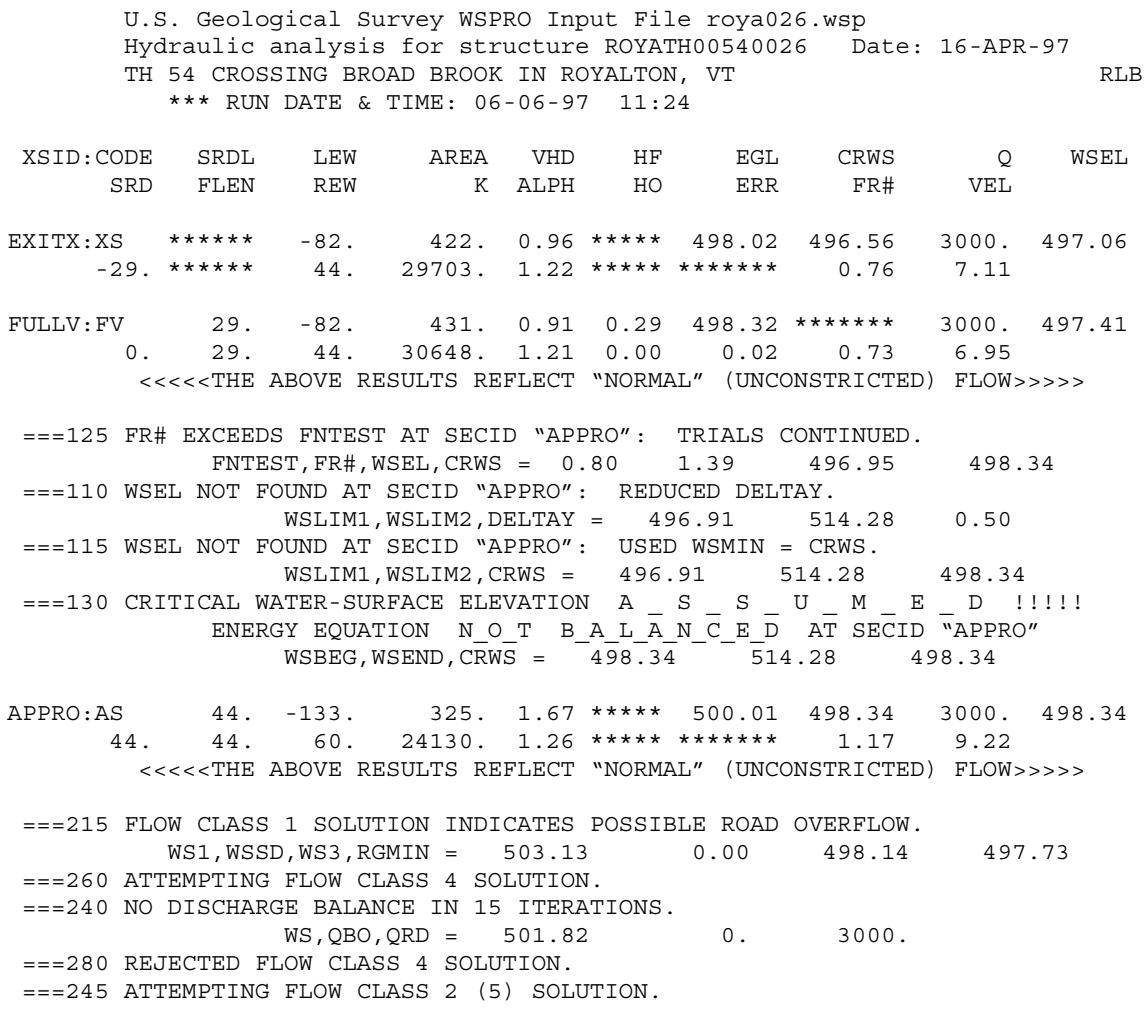

\begin{tabular}{|c|c|c|c|c|c|c|c|c|}
\hline XSID : CODE & SRD & LEW & REW & $\mathrm{Q}$ & $\mathrm{K}$ & AREA & VEL & WSEL \\
\hline EXITX:XS & -29 & -82. & 44. & 3000 . & 29703. & 422 . & 7.11 & 497.06 \\
\hline FULLV : FV & 0 . & -82 . & 44. & 3000. & 30648 . & 431. & 6.95 & 497.41 \\
\hline BRIDG : BR & 0 . & 0 & 23. & 1701. & 16084 . & 183. & 9.31 & 498.24 \\
\hline RDWAY : RG & 10.* & $\star \star \star \star \star * *$ & 1237. & 1253. & $\star \star \star \star \star \star \star \star *$ & 0 & 2.00 & 500.15 \\
\hline APPRO: AS & 44 & -172. & 71. & 3000 . & 55149. & 751. & 3.99 & 500.37 \\
\hline XSID : CODE & XLKQ & $\mathrm{XRKQ}$ & & & & & & \\
\hline
\end{tabular}

SECOND USER DEFINED TABLE.

\begin{tabular}{|c|c|c|c|c|c|c|c|c|c|}
\hline XSID : CODE & CRWS & FR\# & YMIN & YMAX & $\mathrm{HF}$ & $\mathrm{HO}$ & VHD & EGL & \\
\hline EXITX:XS & 496.56 & 0.76 & 489.58 & $509.28 *$ & $\star * * * *$ & 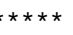 & 0.96 & 498.02 & \\
\hline ULLV : FV & $\star \star \star \star \star *$ & & & 09.55 & 0.29 & 0.00 & & 98.32 & \\
\hline RII & .84 & & & 498.36 * & 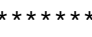 & $* * \star * *$ & .35 & & \\
\hline G & $\star \star \star$ & $\star * * *$ & & 7.24 & $0.08 * *$ & 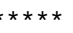 & .35 & 0.64 & \\
\hline PPRO : AS & 498.34 & 0.48 & 489.97 & 514.28 & 0.14 & 0.00 & 0.35 & 500.72 & 500. \\
\hline
\end{tabular}


WSPRO OUTPUT FILE (continued)

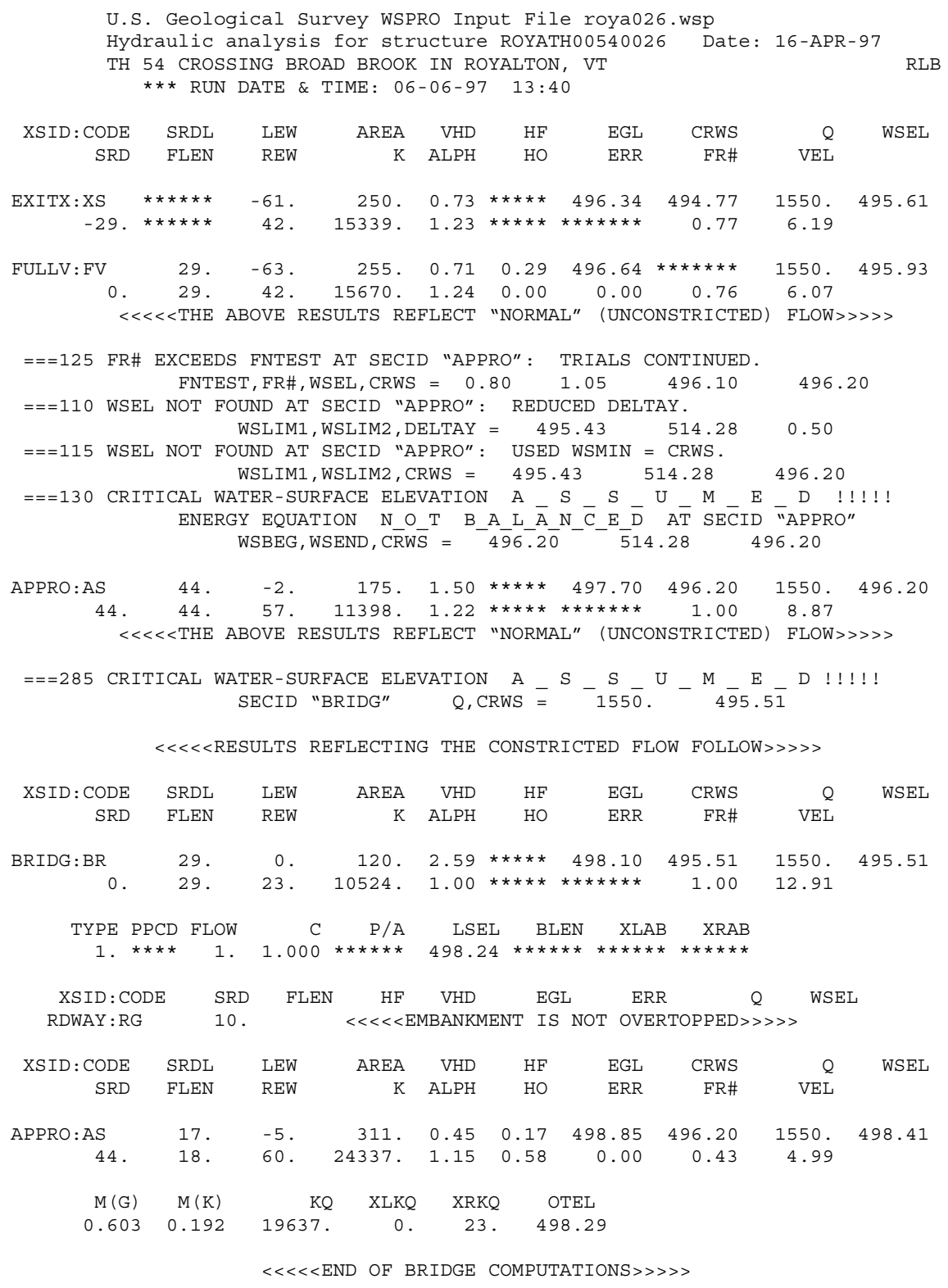

FIRST USER DEFINED TABLE.

\begin{tabular}{|c|c|c|c|c|c|c|c|c|}
\hline XSID : CODE & SRD & LEW & REW & 0 & $\mathrm{~K}$ & AREA & VEL & WSEL \\
\hline EXITX:XS & -29. & -61. & 42 . & 1550. & 15339. & 250. & 6.19 & 495.61 \\
\hline FULLV: FV & 0 & -63. & 42 . & 1550. & 15670 . & 255. & 6.07 & 495.93 \\
\hline BRIDG : BR & 0 . & 0 & 23. & 1550. & 10524 . & 120 & 12.91 & 495.51 \\
\hline RDWAY : RG & \multicolumn{3}{|c|}{ 10. $* * * * * * * * * * * * * *$} & \multicolumn{3}{|c|}{$0 . * * * * * * * * * * * * * * * * * * *$} & \multicolumn{2}{|c|}{$2.00 * * * * * * * *$} \\
\hline APPRO : AS & 44 . & -5 & 60 & 1550. & 24337 . & 311. & 4.99 & 498.41 \\
\hline XSID : CODE & XLKQ & $\mathrm{XRKQ}$ & & & & & & \\
\hline APPRO : AS & 0. & 23. & $1963^{\circ}$ & & & & & \\
\hline
\end{tabular}

SECOND USER DEFINED TABLE.

$\begin{array}{lcrrrrrrrr}\text { XSID : CODE } & \text { CRWS } & \text { FR\# } & \text { YMIN } & \text { YMAX } & \text { HF } & \text { HO } & \text { VHD } & \text { EGL } & \text { WSEL } \\ \text { EXITX:XS } & 494.77 & 0.77 & 489.58 & 509.28 * * * * * * * * * * & 0.73 & 496.34 & 495.61 \\ \text { FULLV:FV } & * * * * * * * * & 0.76 & 489.85 & 509.55 & 0.29 & 0.00 & 0.71 & 496.64 & 495.93 \\ \text { BRIDG : BR } & 495.51 & 1.00 & 489.17 & 498.36 * * * * * * * * * * & 2.59 & 498.10 & 495.51 \\ \text { RDWAY:RG } & * * * * * * * * * * * * * * * & 499.73 & 507.24 * * * * * * * * * * * * * * * * * * * * * * * * * * * * * * * \\ \text { APPRO:AS } & 496.20 & 0.43 & 489.97 & 514.28 & 0.17 & 0.58 & 0.45 & 498.85 & 498.41\end{array}$




\section{APPENDIX C:}

\section{BED-MATERIAL PARTICLE-SIZE DISTRIBUTION}




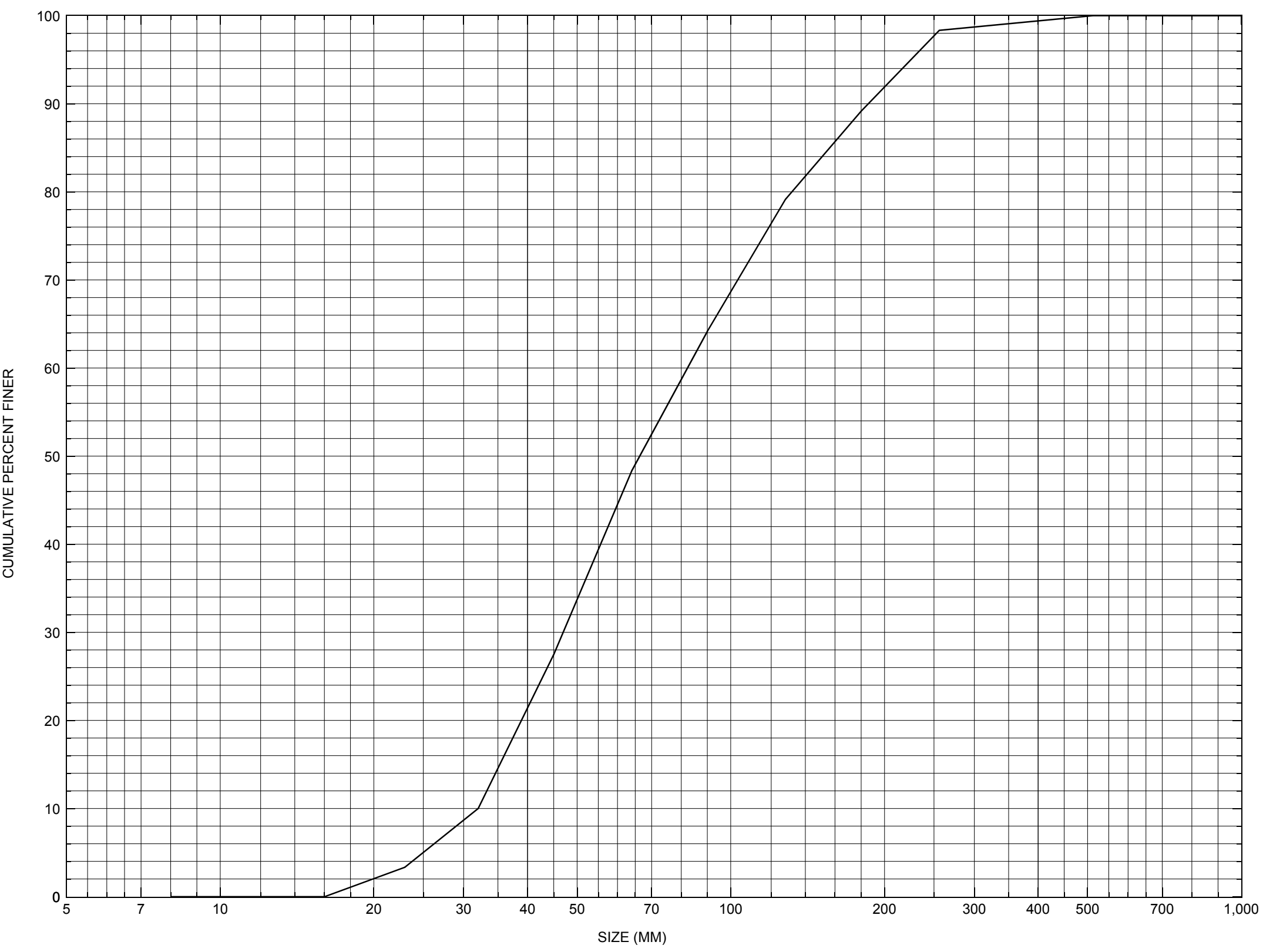

Appendix C. Bed material particle-size distribution for a pebble count in the channel approach of structure ROYATH00540026, in Royalton, Vermont. 


\section{APPENDIX D: \\ HISTORICAL DATA FORM}




\section{Structure Number ROYATH00540026}

\section{General Location Descriptive}

Data collected by (First Initial, Full last name) $\mathbf{E}$. BOEHMLER

Date $(M M / D D / Y Y) \_\mathbf{0 3} / \underline{23} / \underline{95}$

Highway District Number (I - 2; nn) $\mathbf{0 4}$

Town (FIPS place code; I - 4; nnnnn) $\mathbf{6 0 8 5 0}$

Waterway (I - 6) BROAD BROOK

Route Number TH054

Topographic Map South Royalton

Latitude (I - 16; nnnn.n) $\mathbf{4 3 4 6 3}$
County (FIPS county code; I - 3; nnn)

Mile marker (I - 11; nnn.nnn) $\mathbf{0 0 0 0 0 0}$

Road Name (I - 7): -

Vicinity (l - 9) AT JCT TH 54 \& TH 2

Hydrologic Unit Code: $\mathbf{0 1 0 8 0 1 0 5}$

Longitude (i - 17; nnnnn.n) $\mathbf{7 2 3 1 7}$

\section{Select Federal Inventory Codes}

FHWA Structure Number (I - 8) 10141600261416

Maintenance responsibility $(I-21 ; n n) \quad \mathbf{0 3} \quad$ Maximum span length $(I-48 ; n n n n) \underline{\mathbf{0 0 2 4}}$

Year built (I - 27; YYYY) 1930

Structure length (I - 49; nnnnnn) $\underline{\mathbf{0 0 0 0 2 9}}$

Average daily traffic, ADT (I - 29; nnnnnn) $\underline{000020}$

Deck Width (I - 52; nn.n) 160

Year of ADT (I - 30; YY) $\mathbf{9 0}$

Channel \& Protection $(I-61 ; n) \underline{\mathbf{6}}$

Opening skew to Roadway $(I-34 ; n n) \quad \mathbf{0 0}$

Waterway adequacy $(I-71 ; n)$

Operational status $(I-41 ; X) \quad \mathbf{B}$

Underwater Inspection Frequency $(I-92 B ; X Y Y) \_\mathbf{N}$

Structure type (I- 43; nnn) $\mathbf{3 0 2}$

Year Reconstructed (I - 106) 1992

Approach span structure type (I - 44; nnn) $\mathbf{0 0 0}$

Clear span (nnn.n ft) _

Number of spans (I - 45; nnn) $\underline{\mathbf{0 0 1}}$

Vertical clearance from streambed (nnn.n ft) $\underline{\mathbf{0 0 8 . 0}}$

Number of approach spans (I - 46; nnnn) $\mathbf{0 0 0 0}$

Waterway of full opening $\left(n n n . n \mathrm{ft}^{2}\right)$

Comments:

The structural inspection report of $6 / 21 / 94$ indicates the structure is a steel stringer type bridge with a timber deck. Both abutments are "laid-up" stone, but the left abutment has newer concrete facing. The right abutment is reported as having some randomly distributed voids in the stone wall. The report notes that the upstream end apparently has shifted toward the stream slightly, but overall there are no areas of stones cracking or major displacement. The footing along the left abutment is reported as exposed but not undermined. The waterway makes a moderate bend into the crossing with a large portion of the flow directed into the upstream end of the left abutment. There is some large stone fill (Continued, page 33) 


\section{Bridge Hydrologic Data}

Is there hydrologic data available? $\underline{\mathbf{N}}$ if No, type ctrl-n $h \quad$ VTAOT Drainage area $\left(m i^{2}\right)$ : -

Terrain character:

Stream character \& type: -

Streambed material:

Discharge Data (cfs):

$$
\begin{aligned}
& Q_{2.33}- \\
& Q_{50}-
\end{aligned}
$$

Record flood date $(M M / D D / Y Y)$ :

Estimated Discharge (cfs): Ice conditions (Heavy, Moderate, Light) : -

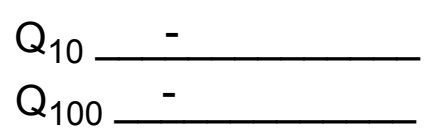

$$
\begin{aligned}
& Q_{25}- \\
& Q_{500}-
\end{aligned}
$$

Water surface elevation $(f t):-$

The stage increases to maximum highwater elevation (Rapidly, Not rapidly):

The stream response is (Flashy, Not flashy):

Describe any significant site conditions upstream or downstream that may influence the stream's stage: -

Watershed storage area (in percent): _ _ \%

The watershed storage area is: - (1-mainly at the headwaters; 2- uniformly distributed; 3-immediatly upstream oi the site)

Water Surface Elevation Estimates for Existing Structure:

\begin{tabular}{|l|l|l|l|l|l|}
\hline Peak discharge frequency & $Q_{2.33}$ & $Q_{10}$ & $Q_{25}$ & $Q_{50}$ & $Q_{100}$ \\
Water surface elevation (ft)) & - & - & - & - & - \\
Velocity (ft/sec) & - & - & - & - & - \\
\hline
\end{tabular}

Long term stream bed changes: -

Is the roadway overtopped below the $\mathrm{Q}_{100}$ ? (Yes, No, Unknown): $\mathbf{U}$ Frequency: Relief Elevation (ft): Discharge over roadway at $Q_{100}\left(f^{3} / \mathrm{sec}\right)$ :

Are there other structures nearby? (Yes, No, Unknown): $\underline{\mathbf{U}}$ Upstream distance (miles): Town: If No or Unknown, type ctrl-n os Highway No. : Structure No. : Year Built:

Clear span (ft): Clear Height $(f t)$ : Full Waterway $\left(f^{2}\right)$ : 
Downstream distance (miles): Town: Year Built:

Highway No. : Structure No. : Structure Type:

Clear span (ft): Clear Height $(f t)$ : Full Waterway $\left(f^{2}\right)$ :

Comments:

riprap placed in this area on the left abutment. The streambed is noted as consisting of stone and gravel with some randomly distributed boulders. Channel scour is noted as minor, while debris accumulation and bank erosion are noted as not evident.

\section{USGS Watershed Data}

Watershed Hydrographic Data Drainage area $(D A) \frac{\mathbf{1 1 . 8 8}}{\mathrm{mi}^{2}}$
Watershed storage $(S T) \quad \mathbf{0}$

Bridge site elevation

Main channel length $\mathbf{5 . 4 2} \mathrm{mi}$

$10 \%$ channel length elevation $\quad \mathbf{8 7 0}$

Lake/pond/swamp area $\underline{0}$ $\mathrm{mi}^{2}$

Main channel slope $(S) \quad \mathbf{1 2 1 . 8} \mathrm{ft} / \mathrm{mi}$

Watershed Precipitation Data

Average site precipitation in Average headwater precipitation in

Maximum 2yr-24hr precipitation event $(124,2)$ in

Average seasonal snowfall (Sn) $\mathrm{ft}$ 


\section{Bridge Plan Data}

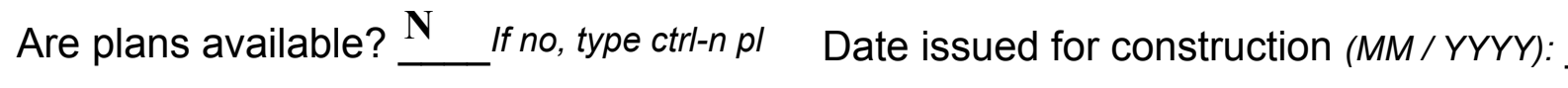

Project Number

Minimum channel bed elevation:

Low superstructure elevation: USLAB DSLAB USRAB DSRAB Benchmark location description:

NO BENCHMARK INFORMATION

Reference Point (MSL, Arbitrary, Other): Datum (NAD27, NAD83, Other):

Foundation Type: 4

If 1 : Footing Thickness

If 2: Pile Type:

If 3: Footing bottom elevation:

Is boring information available? $\mathbf{N}$

Foundation Material Type: $\mathbf{3}$

(1-Spreadfooting; 2-Pile; 3- Gravity; 4-Unknown)

Footing bottom elevation: -

Briefly describe material at foundation bottom elevation or around piles:

NO FOUNDATION MATERIAL INFORMATION

Comments:

NO PLANS. 


\section{Cross-sectional Data}

Is cross-sectional data available? Yes If no, type ctrl-n xs

Source (FEMA, VTAOT, Other)? VTAOT

The station and low chord to bed differences are from a sketch of the upstream face dated 6/ Comments: $22 / 94$ that is attached to a bridge inspection report. The low chord coordinate is taken from the downstream face survey done for this report on 7/11/96.

\begin{tabular}{|l|l|l|l|l|l|l|l|l|l|l|l|}
\hline Station & $\mathbf{0}$ & $\mathbf{1 . 4 2}$ & $\mathbf{1 . 4 3}$ & $\mathbf{5 . 4 3}$ & $\mathbf{1 2}$ & $\mathbf{2 0}$ & $\mathbf{2 4}$ & & - & - & - \\
\hline Feature & LAB & - & - & - & - & - & $\mathrm{RAB}$ & - & - & - & - \\
\hline $\begin{array}{l}\text { Low cord } \\
\text { elevation }\end{array}$ & 498.2 & $\mathbf{4 9 8 . 2}$ & $\mathbf{4 9 8 . 2}$ & $\mathbf{4 9 8 . 2}$ & $\mathbf{4 9 8 . 2}$ & $\mathbf{4 9 8 . 2}$ & $\mathbf{4 9 8 . 2}$ & - & - & - & - \\
\hline $\begin{array}{l}\text { Bed } \\
\text { elevation }\end{array}$ & 491.4 & 491.4 & $\mathbf{4 9 1 . 0}$ & $\mathbf{4 9 0 . 2}$ & $\mathbf{4 8 9 . 9}$ & $\mathbf{4 8 9 . 9}$ & $\mathbf{4 9 0 . 8}$ & - & - & - & - \\
\hline $\begin{array}{l}\text { Low cord to } \\
\text { bed length }\end{array}$ & $\mathbf{6 . 8}$ & $\mathbf{6 . 8}$ & $\mathbf{7 . 2}$ & $\mathbf{8 . 0}$ & $\mathbf{8 . 3}$ & $\mathbf{8 . 3}$ & $\mathbf{7 . 4}$ & - & - & - & - \\
\hline Station & - & - & - & - & - & - & - & - & - & - & - \\
\hline Feature & - & - & - & - & - & - & - & - & - & - & - \\
\hline $\begin{array}{l}\text { Low cord } \\
\text { elevation }\end{array}$ & - & - & - & - & - & - & - & - & - & - & - \\
\hline $\begin{array}{l}\text { Bed } \\
\text { elevation }\end{array}$ & - & - & - & - & - & - & - & - & - & - & - \\
\hline $\begin{array}{l}\text { Low cord to } \\
\text { bed length }\end{array}$ & - & - & - & - & - & - & - & - & - & - & - \\
\hline
\end{tabular}

Source (FEMA, VTAOT, Other)?

Comments: -

\begin{tabular}{|l|l|l|l|l|l|l|l|l|l|l|l|}
\hline Station & - & - & - & - & - & - & - & - & - & - & - \\
\hline Feature & - & - & - & - & - & - & - & - & - & - & - \\
\hline $\begin{array}{l}\text { Low cord } \\
\text { elevation }\end{array}$ & - & - & - & - & - & - & - & - & - & - & - \\
\hline $\begin{array}{l}\text { Bed } \\
\text { elevation }\end{array}$ & - & - & - & - & - & - & - & - & - & - & - \\
\hline $\begin{array}{l}\text { Low cord to } \\
\text { bed length }\end{array}$ & - & - & - & - & - & - & - & - & - & - & - \\
\hline Station & - & - & - & - & - & - & - & - & - & - & - \\
\hline Feature & - & - & - & - & - & - & - & - & - & - & - \\
\hline $\begin{array}{l}\text { Low cord } \\
\text { elevation }\end{array}$ & - & - & - & - & - & - & - & - & - & - & - \\
\hline $\begin{array}{l}\text { Bed } \\
\text { levation }\end{array}$ & - & - & - & - & - & - & - & - & - & - & - \\
\hline $\begin{array}{l}\text { Low cord to } \\
\text { bed length }\end{array}$ & - & - & - & - & - & - & - & - & - & - & - \\
\hline
\end{tabular}




\section{APPENDIX E: \\ LEVEL I DATA FORM}


U. S. Geological Survey

Bridge Field Data Collection and Processing Form

Qa/Qc Check by: $\underline{\mathbf{R B}}$ Date: $\underline{10 / 03 / 96}$

\section{Structure Number}

ROYATH00540026

Computerized by: $\underline{\mathbf{R B}}$ Date: 10/03/96

Reviewd by: $\quad$ RB Date: 06/11/97

\section{A. General Location Descriptive}

1. Data collected by (First Initial, Full last name) M. WEBER

Date $(M M / D D / Y Y)$

04

2. Highway District Number $\mathbf{0 4}$

County 027

Waterway (l - 6) BROAD BROOK

Route Number $\mathbf{T H 0 5 4}$

3. Descriptive comments:

Located at the junction of TH54 and TH2.
Mile marker $\mathbf{0 0 0 0}$

Town 60850

Road Name -

Hydrologic Unit Code: $\mathbf{0 1 0 8 0 1 0 5}$

\section{B. Bridge Deck Observations}
4. Surface cover... LBUS 4
RBUS 6
LBDS 4
RBDS 6
Overall 6

(2b us, ds,lb,rb: 1- Urban; 2- Suburban; 3- Row crops; 4- Pasture; 5- Shrub- and brushland; 6- Forest; 7- Wetland)
5. Ambient water surface...US $\underline{2}$
UB 2
DS $\underline{2}$
(1- pool; 2- riffle)

6. Bridge structure type 1 (1- single span; 2- multiple span; 3- single arch; 4- multiple arch; 5-cylindrical culvert; 6- box culvert; or 7- other)
7. Bridge length $\underline{29}$ (feet)
Span length 24
(feet)
Bridge width 16 (feet)

\section{Road approach to bridge:}
8. LB 1
RB 2
( 0 even, 1- lower, 2- higher)
9. LB_2
RB $\underline{2}$
(1- Paved, 2- Not paved)

10. Embankment slope (run / rise in feet / foot)

US left

US right

\begin{tabular}{|c|c|c|c|}
\hline \multicolumn{2}{|c|}{ Protection } & \multirow{2}{*}{ 13.Erosion } & 14.Severity \\
\hline 11.Type & 12.Cond. & $\mathbf{0}$ & - \\
\hline $\mathbf{2}$ & $\mathbf{1}$ & $\mathbf{0}$ & - \\
$\mathbf{0}$ & - & $\underline{\mathbf{2}}$ & $\mathbf{1}$ \\
\hline $\mathbf{0}$ & - & $\underline{\mathbf{2}}$ & $\mathbf{1}$ \\
\hline $\mathbf{0}$ & - & $\mathbf{0}$ & - \\
\hline
\end{tabular}

Bank protection types: 0- none; 1- < 12 inches;

2- < 36 inches; 3- < 48 inches;

4- < 60 inches; 5- wall / artificial levee

Bank protection conditions: 1- good; 2- slumped;

3- eroded; 4- failed

Erosion: 0 - none; 1- channel erosion; 2 -

road wash; 3- both; 4- other

Erosion Severity: 0 - none; 1- slight; 2- moderate;

\section{Channel approach to bridge (BF):}

15. Angle of approach: $\mathbf{1 0}$

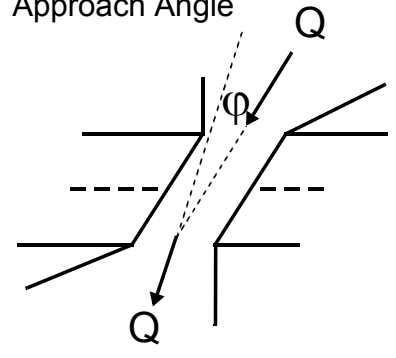

17. Channel impact zone 1:

Where? LB $(L B, R B)$

Range? 3 feet US

Channel impact zone 2:

Where? RB (LB, RB)

Range? 10 feet $\underline{\mathbf{U B}}$ (US, UB, DS) to

Impact Severity: 0- none to very slight; 1- Slight; 2- Moderate; 3- Severe
16. Bridge skew: 20 Bridge Skew Angle

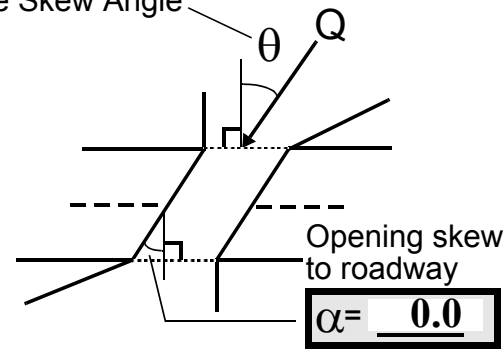

\section{Exist? $\mathbf{Y}(Y$ or $N)$}

Severity 2

US, UB, DS) to $\underline{\mathbf{5 0}}$ feet $\underline{\mathbf{U S}}$

Exist? $\underline{\mathbf{Y}}(\mathrm{Y}$ or $N)$

Severity 2

feet DS


18. Bridge Type: 1a

1a- Vertical abutments with wingwalls

1 b- Vertical abutments without wingwalls

2- Vertical abutments and wingwalls, sloping embankment Wingwalls perpendicular to abut. face

3- Spill through abutments

4- Sloping embankment, vertical wingwalls and abutments

Wingwall angle less than $90^{\circ}$.

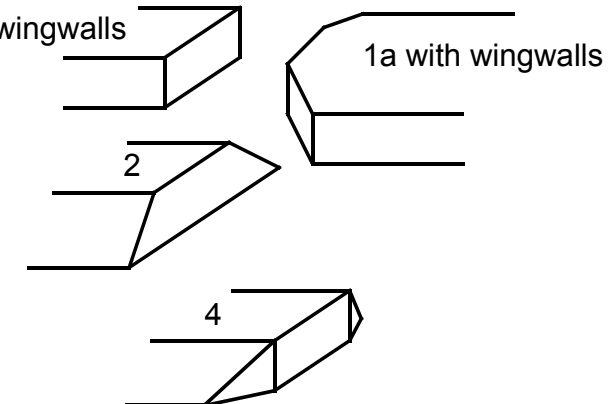

19. Bridge Deck Comments (surface cover variations, measured bridge and span lengths, bridge type variations, approach overflow width, etc.)

7. Values are from the VT AOT files. Measured bridge length is $26 \mathrm{ft}$, span length is $23 \mathrm{ft}$ and the bridge width is $16 \mathrm{ft}$. Lengths were measured at the US bridge face. The structure length is from the left edge of the concrete of the left abutment to the right end of the wooden deck which overlaps the right abutment by $2 \mathrm{ft}$.

4. The left bank is pasture while the right bank is forested, however since the immediate banks are also forested on the left bank US and DS, the overall surface cover is forest.

11. The US left road approach protection is at the US end of the wingwall. Gravel road fill material is apparent at all road approaches.

18. On the right abutment, the wingwalls are parallel to the road.

The abutments were originally dry wall stonework. There is a newer concrete facing as well as concrete wingwalls on the left abutment.

\section{Upstream Channel Assessment}

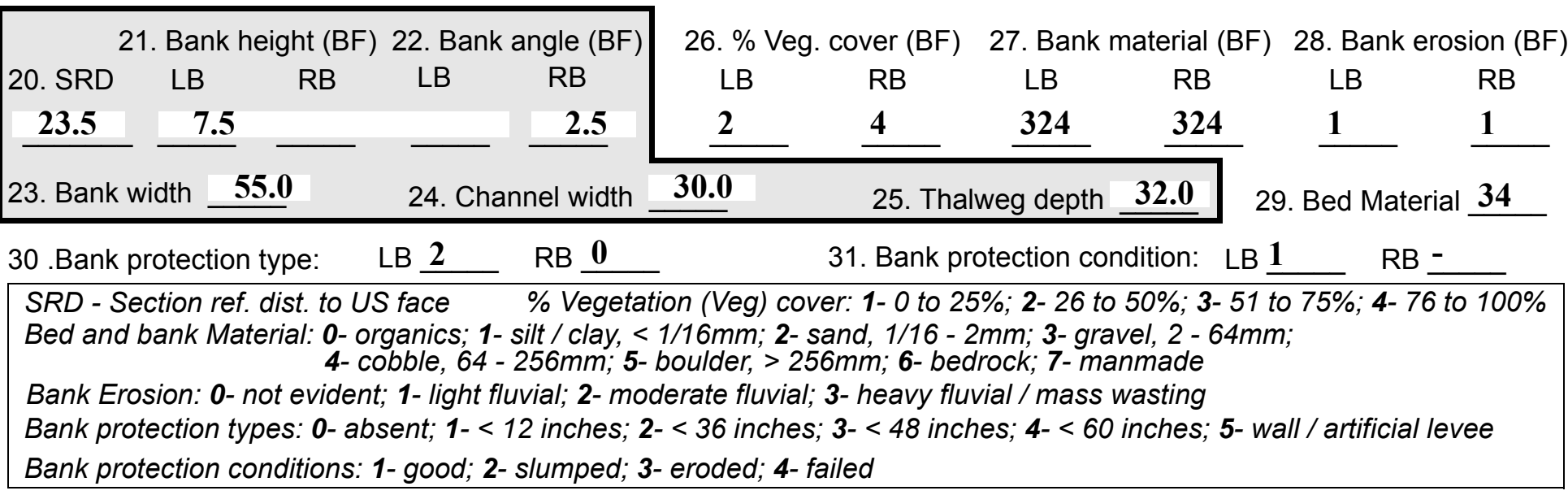

32. Comments (bank material variation, minor inflows, protection extent, etc.):

26. The percent vegetation cover on the left bank US is minimal to $50 \mathrm{ft}$ US, then the immediate bank becomes forested.

29. There are boulders and sand on the sides of the channel.

30. The left bank protection is placed type-2 native boulders extending from $10 \mathrm{ft}$ US to $50 \mathrm{ft}$ US, beginning at the middle of the US left wingwall.

The US left wingwall and part of the US left bank is impact zone 1. 
33.Point/Side bar present? $\mathbf{Y}$

$(Y \text { or } N \text {. if } N \text { type ctrl-n } p b)_{34}$. Mid-bar distance: 35

35. Mid-bar width: 9

36. Point bar extent: 10 feet US

(US, UB) to 55 feet $\underline{\mathbf{U S}}$

(US, UB, DS) positioned 70

\%LB to 100 \%RB

37. Material: $\mathbf{3 2 4}$

38. Point or side bar comments (Circle Point or Side; Note additional bars, material variation, status, etc.):

A small amount of grassy vegetation is on the bar.

39. Is a cut-bank present? $\mathbf{N}$ ( $Y$ or if $N$ type ctrl-n $c b)$

40. Where? - $(L B$ or $R B)$

41. Mid-bank distance: -

42. Cut bank extent: -

feet -

(US, UB) to feet (US, UB, DS)

43. Bank damage: -

(1- eroded and/or creep; 2- slip failure; 3- block failure)

44. Cut bank comments (eg. additional cut banks, protection condition, etc.):

NO CUT BANKS

45. Is channel scour present? $\mathbf{N}$ ( $Y$ or if $N$ type ctrl-n cs)

47. Scour dimensions: Length -

Width -

Depth : -

46. Mid-scour distance: -

48. Scour comments (eg. additional scour areas, local scouring process, etc.):

NO CHANNEL SCOUR

49. Are there major confluences? $\mathbf{N}$

51. Confluence 1: Distance -

Confluence 2: Distance -

52. Enters on -

Enters on -

54. Confluence comments (eg. confluence name):

NO MAJOR CONFLUENCES
50. How many? -

53. Type(1- perennial; 2- ephemeral)

Type (1-perennial; 2-ephemeral) ( $L B$ or $R B)$

\section{Under Bridge Channel Assessment}

55. Channel restraint (BF)? LB 2

\begin{tabular}{|ccccc}
\hline \multicolumn{2}{|c}{ 56. Height (BF) } & \multicolumn{3}{c}{57 Angle (BF) } \\
LB & RB & LB & RB \\
$\mathbf{2 3 . 0}$ & & & $\mathbf{1 . 0}$ & \\
\hline
\end{tabular}
(1- natural bank; 2- abutment; 3- artificial levee)

58. Bank width (BF) 59. Channel width (Amb) -

61. Material (BF)

LB RB

$\underline{2} \quad \underline{7}$
62. Erosion (BF)

LB RB

7

63. Bed Material -

Bed and bank Material: 0- organics; 1- silt / clay, < 1/16mm; 2- sand, 1/16 - 2mm; 3- gravel, 2 - 64mm; 4- cobble, 64 - 256mm; 5- boulder, > 256mm; 6- bedrock; 7- manmade

Bank Erosion: 0- not evident; 1- light fluvial; 2- moderate fluvial; 3- heavy fluvial / mass wasting

64. Comments (bank material variation, minor inflows, protection extent, etc.):

345

63. The sides of the channel under the bridge are mostly sand.

Voids in the right abutment stonework mentioned in the historical form are not apparent. The US end of the right abutment is tipping very slightly towards the stream with a deviation from vertical less than $0.5 \mathrm{ft}$. 
65. Debris and Ice Is there debris accumulation?

(Yor $N)$ 66. Where? $\underline{Y}$

(1- Upstream; 2- At bridge; 3- Both)

67. Debris Potential 1 ( 1- Low; 2- Moderate; 3- High)

68. Capture Efficiency 2 (1- Low; 2- Moderate; 3- High)

69. Is there evidence of ice build-up? $\underline{2}$ (Yor $N)$

Ice Blockage Potential $\mathbf{N}$

(1-Low; 2- Moderate; 3- High)

70. Debris and Ice Comments:

1

66. There are some branches and logs caught on the banks US and DS.

68. Since there are two impact zones near the bridge and the bank full width is constricted through the bridge, capture efficiency is moderate.

\begin{tabular}{|l|c|c|c|c|c|c|c|c|}
\hline Abutments & $\begin{array}{c}\text { 71. Attack } \\
\angle \text { (BF) }\end{array}$ & $\begin{array}{c}\text { 72. Slope } \angle \\
\text { (Qmax) }\end{array}$ & $\begin{array}{c}\text { 73. Toe } \\
\text { loc. (BF) }\end{array}$ & $\begin{array}{c}\text { 74. Scour } \\
\text { Condition }\end{array}$ & $\begin{array}{c}75 . \text { Scour } \\
\text { depth }\end{array}$ & $\begin{array}{c}\text { 76. Exposure } \\
\text { depth }\end{array}$ & 77. Material & 78. Length \\
\hline LABUT & & $\mathbf{0}$ & $\mathbf{9 0}$ & $\mathbf{2}$ & $\mathbf{2}$ & $\mathbf{0}$ & $\mathbf{0 . 5}$ & $\mathbf{9 0 . 0}$ \\
\hline RABUT & $\mathbf{1}$ & $\mathbf{2 0}$ & $\mathbf{9 0}$ & & & $\mathbf{2}$ & $\mathbf{1}$ & $\mathbf{2 3 . 5}$ \\
\hline
\end{tabular}

Pushed: $L B$ or RB

Toe Location (Loc.): 0- even, 1- set back, 2- protrudes

Scour cond.: 0- not evident; 1- evident (comment); 2- footing exposed; 3-undermined footing; 4- piling exposed; 5- settled; 6- failed

Materials: 1- Concrete; 2- Stone masonry or drywall; 3- steel or metal; 4- wood

79. Abutment comments (eg. undermined penetration, unusual scour processes, debris, etc.):

1

0

2

77. Both abutments were originally drywall. The left abutment now has a $1 \mathrm{ft}$ thick concrete facing in front of the drywall.

74. Evidence of scour on the right abutment is at the DS end, this area is impact zone 2. Footing exposure on the left abutment is at the US end.

80. Wingwalls:

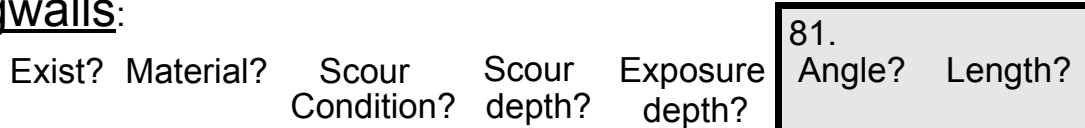

USLWW:

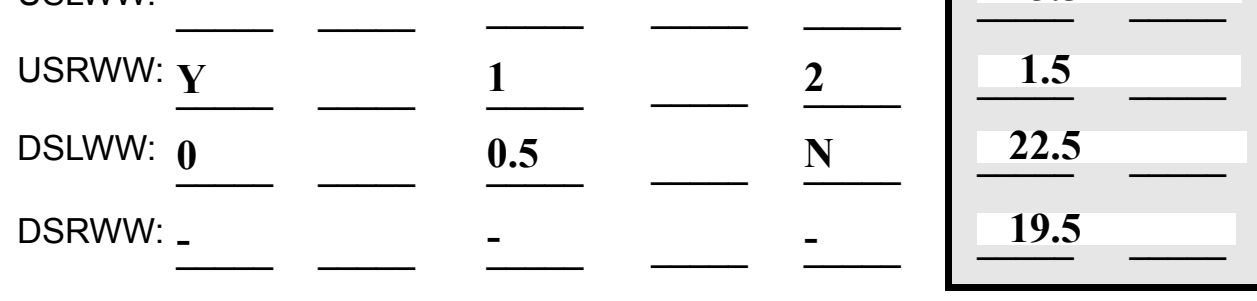

Wingwall materials: 1- Concrete; 2- Stone masonry or drywall; 3- steel or metal; 4- wood

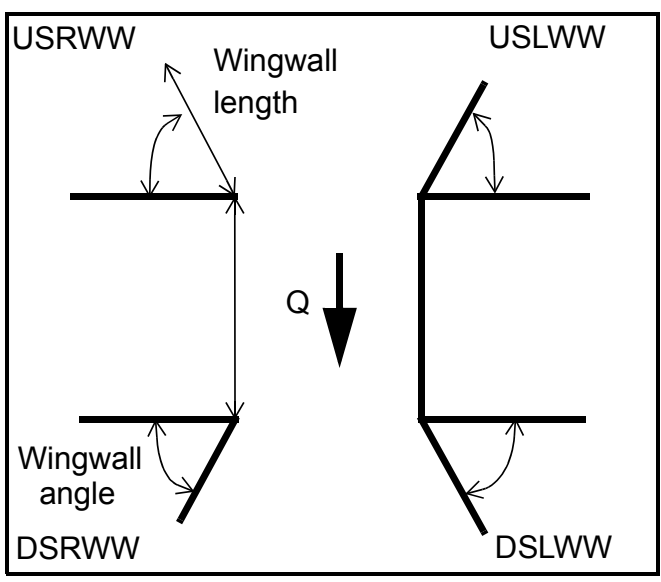

82. Bank / Bridge Protection:

\begin{tabular}{|l|l|l|l|l|l|l|c|c|}
\hline Location & USLWW & USRWW & LABUT & RABUT & LB & RB & DSLWW & DSRWW \\
\hline Type & - & $\mathbf{0}$ & $\mathbf{N}$ & - & $\mathbf{1}$ & - & - & $\mathbf{1}$ \\
\hline Condition & $\mathbf{Y}$ & - & - & - & $\mathbf{2}$ & - & - & $\mathbf{2}$ \\
\hline Extent & $\mathbf{1}$ & - & - & $\mathbf{2}$ & - & $\mathbf{0}$ & $\mathbf{2}$ & - \\
\hline
\end{tabular}

Bank / Bridge protection types: 0- absent; 1- < 12 inches; 2- < 36 inches; 3- < 48 inches; 4- < 60 inches; 
83. Wingwall and protection comments (eg. undermined penetration, unusual scour processes, etc.):

-
-
-
-
-
2
1
1
-
-
-

\section{Piers:}

84. Are there piers? Th (Y or if N type ctrl-n pr)

\begin{tabular}{|l|l|l|l|l|l|l|l|}
\hline \multirow{2}{*}{$\begin{array}{l}85 . \\
\text { Pier no. }\end{array}$} & \multicolumn{3}{|c|}{ width (w) feet } & \multicolumn{3}{c|}{ elevation (e) feet } \\
\cline { 2 - 8 } & w1 & w2 & w3 & e@w1 & e@w2 & e@w3 \\
\hline Pier 1 & & & & $\mathbf{4 0 . 0}$ & $\mathbf{1 2 . 0}$ & $\mathbf{2 5 . 0}$ \\
\hline Pier 2 & & & $\mathbf{6 . 0}$ & $\mathbf{1 0 . 5}$ & $\mathbf{3 5 . 0}$ & $\mathbf{2 0 . 0}$ \\
\hline Pier 3 & & - & - & $\mathbf{1 6 . 0}$ & - & - \\
\hline Pier 4 & - & - & - & - & - & - \\
-
\end{tabular}

\begin{tabular}{|l|l|l|l|l|}
\hline Level 1 Pier Descr. & \multicolumn{1}{|c|}{1} & \multicolumn{1}{|c|}{2} & \multicolumn{1}{|c|}{3} & \multicolumn{1}{|c|}{} \\
\hline 86. Location (BF) & ere are & end of & man & \\
\hline 87. Type & a few & the & place & \\
\hline 88. Material & sub- & right & d & \\
\hline 89. Shape & merg & abut & nativ & \\
\hline 90. Inclined? & ed & ment & e & N \\
\hline 91. Attack $\angle$ (BF) & type- & - & boul- & - \\
\hline 92. Pushed & $\mathbf{2}$ & Pro- & ders. & - \\
\hline 93. Length (feet) & - & - & - & - \\
\hline 94. \# of piles & boul- & tec- & & - \\
\hline 95. Cross-members & ders & tion & & - \\
\hline 96. Scour Condition & at & in all & & - \\
\hline 97. Scour depth & the & cases & & - \\
\hline 98. Exposure depth & US & is & & - \\
\hline
\end{tabular}

LFP, LTB, LB, MCL, MCM, MCR, RB, RTB, RFP

1- Solid pier, 2- column, 3- bent

1-Wood; 2- concrete; 3- metal; 4- stone

1- Round; 2- Square; 3- Pointed

Y-yes; $N$ - no

$L B$ or $R B$

0- none; 1- laterals; 2- diagonals; 3- both

0- not evident; 1- evident (comment);

2- footing exposed; 3- piling exposed;

4- undermined footing; 5- settled; 6- failed 
99. Pier comments (eg. undermined penetration, protection and protection extent, unusual scour processes, etc.):

-
-
-
-
-
-
-
-
-

100.

\section{E. Downstream Channel Assessment}

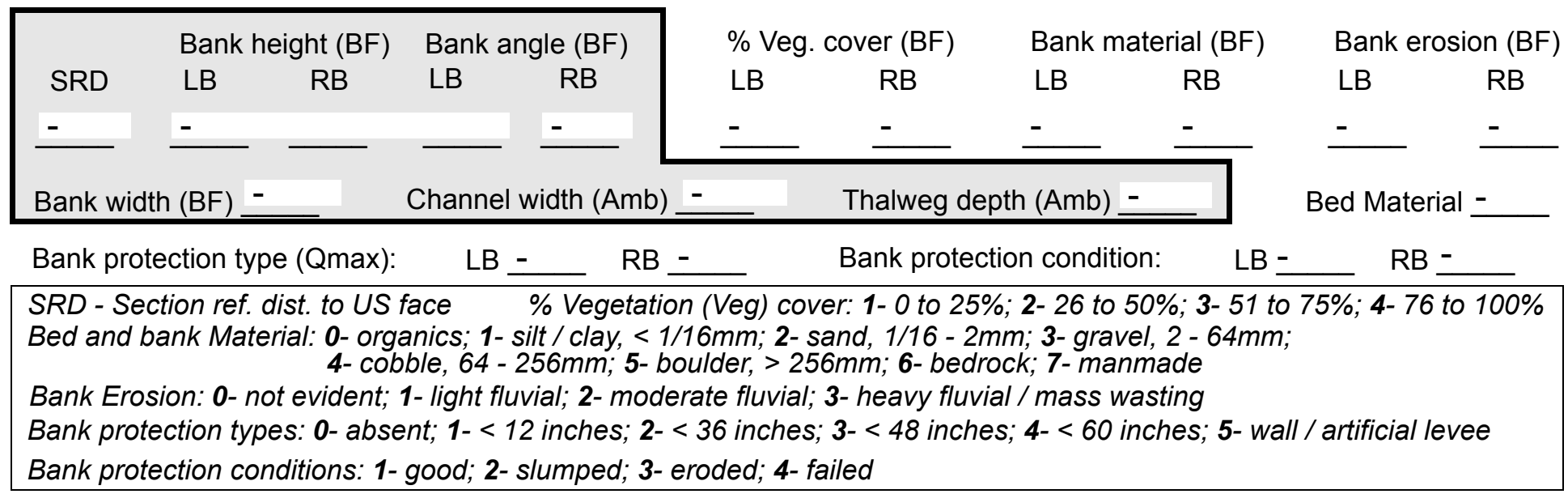

Comments (eg. bank material variation, minor inflows, protection extent, etc.):

$-$

$-$

$-$

$-$

$-$

$-$

$-$

$-$

-

-

-

-

-

-

-

101. Is a drop structure present? _ ( $Y$ or $N$, if $N$ type ctrl-n ds) 102. Distance: __ feet
103. Drop: - feet
104. Structure material: -
(1- steel sheet pile; 2- wood pile; 3- concrete; 4- other)

105. Drop structure comments (eg. downstream scour depth):

-

$-$

-

\section{NO PIERS}


106. Point/Side bar present? (Y or N. if N type ctrl-n pb)Mid-bar distance:

Mid-bar width:

Point bar extent: feet

(US, UB, DS) to feet (US, UB, DS) positioned $\underline{\mathbf{2}}$ $\%$ LB to 4 $\%$ RB

Point or side bar comments (Circle Point or Side; note additional bars, material variation, status, etc.):

234
1
1
324

324

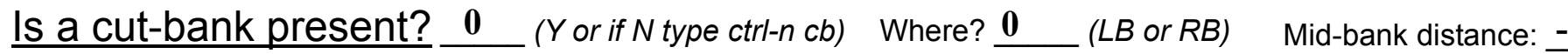
Cut bank extent:

Bank damage: e (1-eroded and/or creep; 2- slip failure; 3- block failure)

Cut bank comments (eg. additional cut banks, protection condition, etc.):

channel for road wash from the right road approach enters at $20 \mathrm{ft}$ DS on the right bank. The percent vegetation cover on the left bank DS is minimal between $15 \mathrm{ft}$ DS and $25 \mathrm{ft}$ DS. There are also some boulders in the channel and on the banks.

Is channel scour present? ( $Y$ or if $N$ type ctrl-n cs)

Mid-scour distance:

Scour dimensions: Length Width Depth:

Positioned $\%$ LB to $\%$ RB

Scour comments (eg. additional scour areas, local scouring process, etc.):

Are there major confluences? $\mathbf{N}$ ( $Y$ or if $N$ type ctrl-n $m c)$ Confluence 1: Distance NO Confluence 2: Distance $\underline{\underline{\text { STR }}}$ Enters on $\underline{\mathbf{D R}}$ (LB or $R B)$ Enters on $\underline{\mathbf{U C}}$ (LB or RB) Confluence comments (eg. confluence name):

RE

\section{F. Geomorphic Channel Assessment}

107. Stage of reach evolution
1- Constructed

2- Stable

3- Aggraded

4- Degraded

5- Laterally unstable

6- Vertically and laterally unstable 
108. Evolution comments (Channel evolution not considering bridge effects; See HEC-20, Figure 1 for geomorphic descriptors):

Y
15
5
10
UB
25
DS
0
15
2




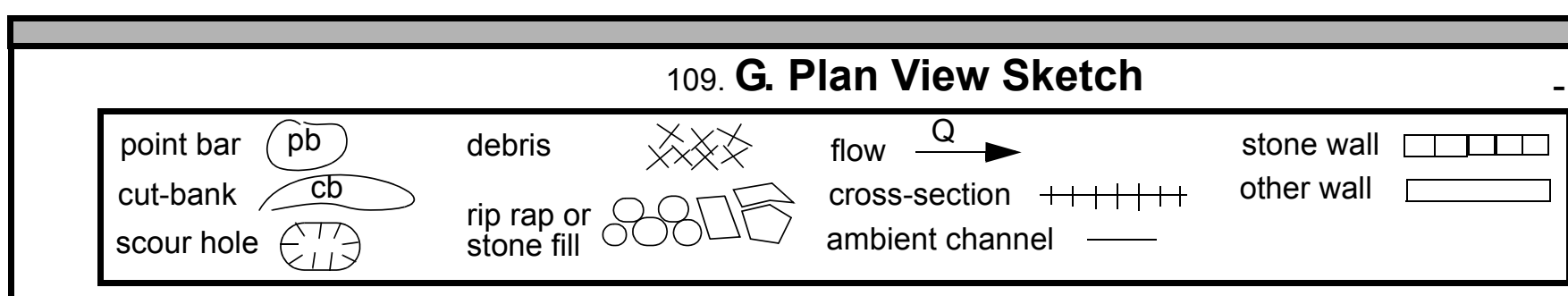

cut-bank $\mathrm{cb}$

scour hole rip rap or
stone fill stone fill cross-section $+1+1+1$ ambient channe other wall 
APPENDIX F:

SCOUR COMPUTATIONS 


\begin{tabular}{|c|c|c|c|}
\hline $\begin{array}{ll}\text { Structure Number: } & \text { ROYATH00540026 } \\
\text { Road Number: } & \text { TH } 54\end{array}$ & & $\begin{array}{l}\text { Town: } \\
\text { County: }\end{array}$ & $\begin{array}{l}\text { ROYALTON } \\
\text { WINDSOR }\end{array}$ \\
\hline Stream: BROAD BROOK & & & \\
\hline Initials RLB & Checked: & RF & \\
\hline Analysis of contraction scour, li & -bed or $\mathrm{C}^{-}$ & lear wat & \\
\hline $\begin{array}{l}\text { Critical Velocity of Bed Material } \\
\text { Vc }=11.21 * \mathrm{y}^{\wedge} 0.1667 * \mathrm{D} 50^{\wedge} 0.33 \text { with }\end{array}$ & $\begin{array}{l}\text { converted } \\
=2.65\end{array}$ & to Engl & sh units) \\
\hline (Richardson and others, 1995, p. & , eq. 16) & & \\
\hline pproach Section & & & \\
\hline Characteristic & $100 \mathrm{yr}$ & $500 \mathrm{yr}$ & other $Q$ \\
\hline Total discharge, cfs & 2200 & 3000 & 1550 \\
\hline Main Channel Area, ft2 & 247 & 265 & 202 \\
\hline Left overbank area, ft2 & 212 & 304 & 0 \\
\hline Right overbank area, ft2 & 158 & 183 & 109 \\
\hline Top width main channel, ft & 32 & 32 & 32 \\
\hline Top width L overbank, ft & 162 & 166 & 0 \\
\hline Top width $\mathrm{R}$ overbank, ft & 42 & 45 & 33 \\
\hline D50 of channel, ft & 0.218 & 0.218 & 0.218 \\
\hline D50 left overbank, ft & -- & -- & -- \\
\hline D50 right overbank, ft & -- & -- & -- \\
\hline $\mathrm{Y}_{1}$, average depth, MC, ft & 7.7 & 8.3 & 6.3 \\
\hline Y1, average depth, LOB, ft & 1.3 & 1.8 & ERR \\
\hline Y1, average depth, ROB, ft & 3.8 & 4.1 & 3.3 \\
\hline Total conveyance, approach & 43198 & 55129 & 24350 \\
\hline Conveyance, main channel & 25617 & 28784 & 18518 \\
\hline Conveyance, LOB & 8374 & 15014 & 0 \\
\hline Conveyance, ROB & 9206 & 11331 & 5832 \\
\hline Percent discrepancy, conveyance & 0.0023 & 0.0000 & 0.0000 \\
\hline Qm, discharge, $\mathrm{MC}$, cfs & 1304.6 & 1566.4 & 1178.8 \\
\hline Q1, discharge, LOB, cfs & 426.5 & 817.0 & 0.0 \\
\hline Qr, discharge, ROB, Cfs & 468.8 & 616.6 & 371.2 \\
\hline Vm, mean velocity $\mathrm{MC}$, ft/s & 5.3 & 5.9 & 5.8 \\
\hline VI, mean velocity, LOB, ft/s & 2.0 & 2.7 & ERR \\
\hline Vr, mean velocity, ROB, ft/s & 3.0 & 3.4 & 3.4 \\
\hline Vc-m, crit. velocity, MC, ft/s & 9.5 & 9.6 & 9.2 \\
\hline Vc-1, crit. velocity, LOB, ft/s & ERR & ERR & ERR \\
\hline Vc-r, crit. velocity, ROB, ft/s & ERR & ERR & ERR \\
\hline Results & & & \\
\hline Live-bed(1) or Clear-Water(0) Con & action $\mathrm{Sc}$ & our? & \\
\hline Main Channel & 0 & 0 & 0 \\
\hline Left Overbank & $\mathrm{N} / \mathrm{A}$ & $\mathrm{N} / \mathrm{A}$ & $\mathrm{N} / \mathrm{A}$ \\
\hline Right Overbank & $\mathrm{N} / \mathrm{A}$ & $\mathrm{N} / \mathrm{A}$ & $\mathrm{N} / \mathrm{A}$ \\
\hline
\end{tabular}


Clear water Contraction Scour in MAIN CHANNEL

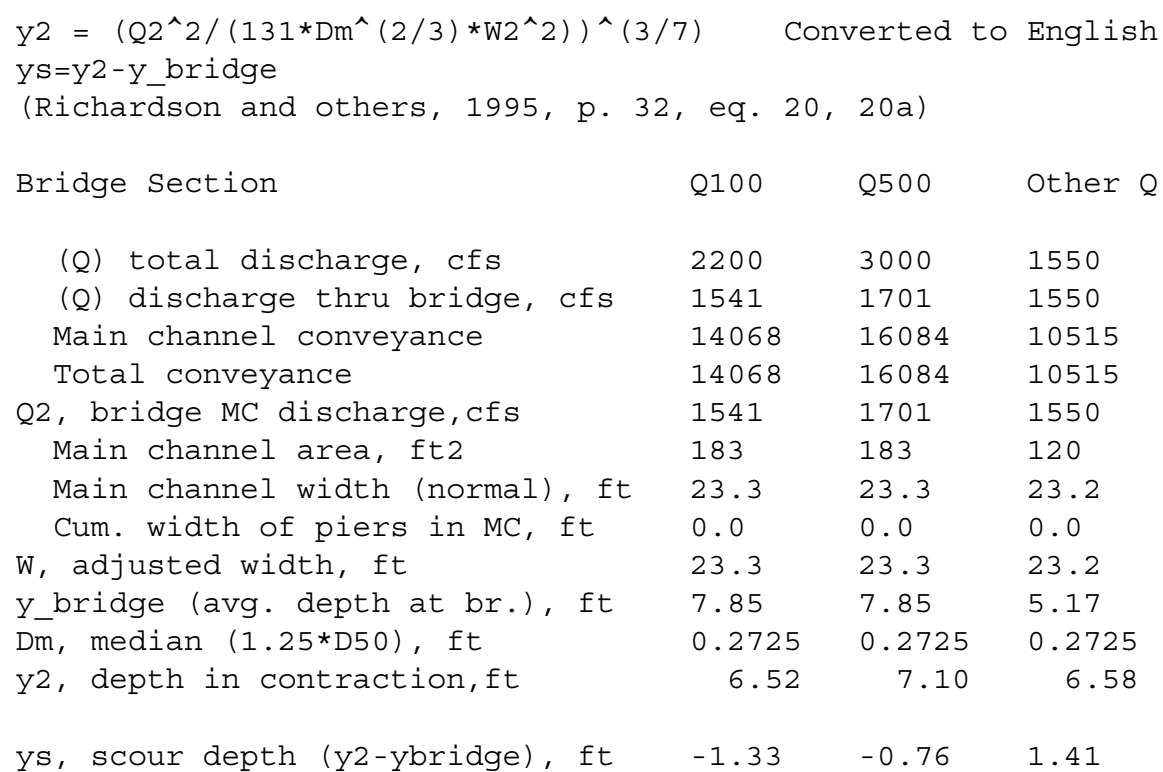

Pressure Flow Scour (contraction scour for orifice flow conditions)

Chang pressure flow equation $\quad \mathrm{Hb}+\mathrm{Ys}=\mathrm{Cq} * \mathrm{qb} / \mathrm{VC}$

$\mathrm{Cq}=1 / \mathrm{Cf} * \mathrm{CC} \quad \mathrm{Cf}=1.5 * \mathrm{Fr}^{\wedge} 0.43 \quad(<=1) \quad \mathrm{CC}=\mathrm{SQRT}[0.10(\mathrm{Hb} /(\mathrm{ya}-\mathrm{w})-0.56)]+0.79 \quad(<=1)$

Umbrell pressure flow equation

$(\mathrm{Hb}+\mathrm{Ys}) / \mathrm{ya}=1.1021 *[(1-\mathrm{w} / \mathrm{ya}) *(\mathrm{Va} / \mathrm{VC})]^{\wedge} 0.6031$

(Richardson and other, 1995, p. 144-146)

Q, total, cfs

Q100 Q500 OtherQ

Q, thru bridge MC, cfs

$2200 \quad 3000 \quad 1550$

$\mathrm{Vc}$, critical velocity, ft/s

$1541 \quad 1701 \quad 1550$

$\begin{array}{llll}\mathrm{Va}, \text { velocity MC approach, ft/s } & 5.28 & 5.91 & 5.84\end{array}$

Main channel width (normal), ft $23.3 \quad 23.3 \quad 23.2$

Cum. width of piers in MC, ft $0.0 \quad 0.0 \quad 0.0$

W, adjusted width, ft

$\begin{array}{lll}23.3 & 23.3 & 23.2\end{array}$

qbr, unit discharge, ft2/s

Area of full opening, ft2

$\begin{array}{lll}66.1 & 73.0 & 66.8\end{array}$

$\mathrm{Hb}$, depth of full opening, ft

$183.0 \quad 183.0 \quad 120.0$

Fr, Froude number, bridge MC

$\begin{array}{lll}7.85 & 7.85 & 5.17\end{array}$

**Area at downstream face, ft2 148

**Hb, depth at downstream face, ft 6.35

**Fr, Froude number at DS face 0.73

$* \star C f$, for downstream face $(<=1.0)$

1.00

0.59

1.00

1

1.00

$164 \quad \mathrm{~N} / \mathrm{A}$

$7.04 \quad \mathrm{~N} / \mathrm{A}$

$0.69 \quad \mathrm{ERR}$

$1.00 \quad \mathrm{~N} / \mathrm{A}$ 


$\begin{array}{llll}\text { Elevation of Low Steel, ft } & 498.24 & 498.24 & 498.24 \\ \text { Elevation of Bed, ft } & 490.39 & 490.39 & 493.07 \\ \text { Elevation of Approach, ft } & 499.81 & 500.37 & 498.41 \\ \text { Friction loss, approach, ft } & 0.11 & 0.14 & 0.17 \\ \text { Elevation of WS immediately US, ft } & 499.70 & 500.23 & 498.24 \\ \text { ya, depth immediately US, ft } & 9.31 & 9.84 & 5.17 \\ \text { Mean elevation of deck, ft } & 499.91 & 499.91 & 499.91 \\ \text { w, depth of overflow, ft (>=0) } & 0.00 & 0.32 & 0.00 \\ \text { Cc, vert contrac correction (<=1.0) } & 0.96 & 0.95 & 1.00 \\ \text { * CC, for downstream face (<=1.0) } & 0.900441 & 0.923804 & \text { ERR } \\ \text { Ys, scour w/Chang equation, ft } & -0.58 & 0.13 & 2.11 \\ \text { Ys, scour w/Umbrell equation, ft } & -0.64 & 0.09 & -0.83\end{array}$

**=for UNsubmerged orifice flow using estimated downstream bridge face properties.

**Ys, scour w/Chang equation, ft $1.39 \quad 1.20 \quad \mathrm{~N} / \mathrm{A}$

**Ys, scour w/Umbrell equation, ft $0.86 \quad 0.90 \quad \mathrm{~N} / \mathrm{A}$

In UNsubmerged orifice flow, an adjusted scour depth using the Laursen equation results and the estimated downstream bridge face properties can also be computed (ys=y2-ybridgeDS)

Y2, from Laursen's equation, ft $6.52 \quad 7.10 \quad 6.58$

WSEL at downstream face, ft $496.71 \quad 497.41 \quad--$

Depth at downstream face, ft $6.35 \quad 7.04 \quad \mathrm{~N} / \mathrm{A}$

Ys, depth of scour (Laursen), ft $0.17 \quad 0.06 \quad$ N/A

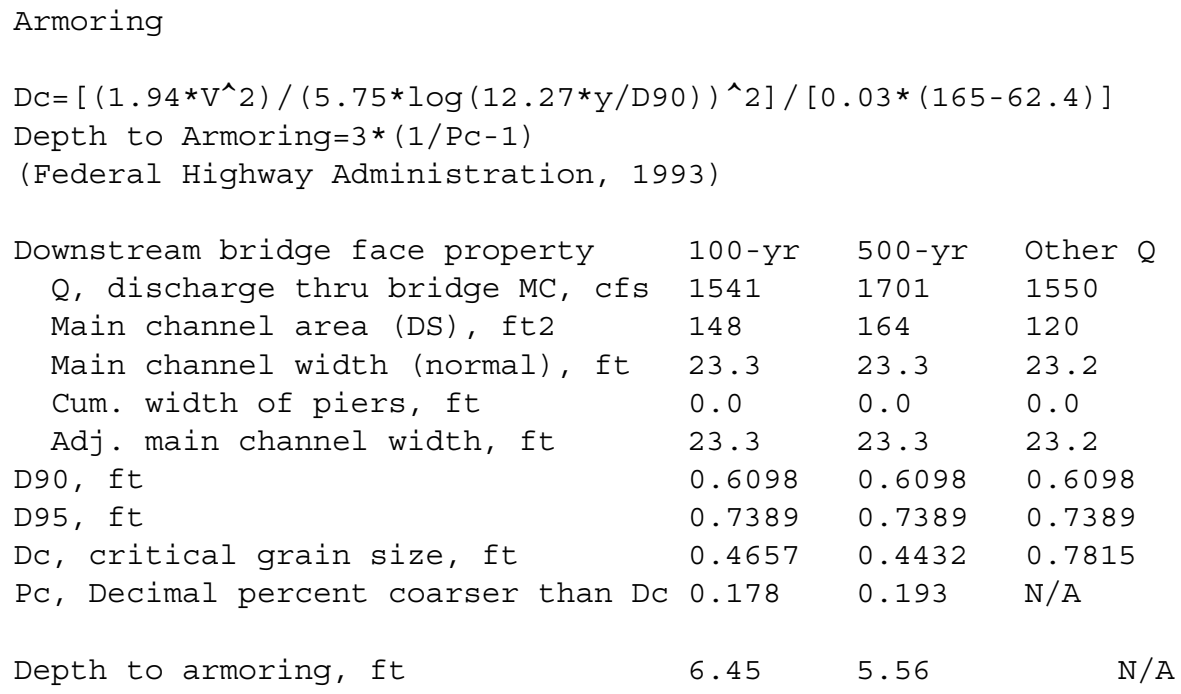




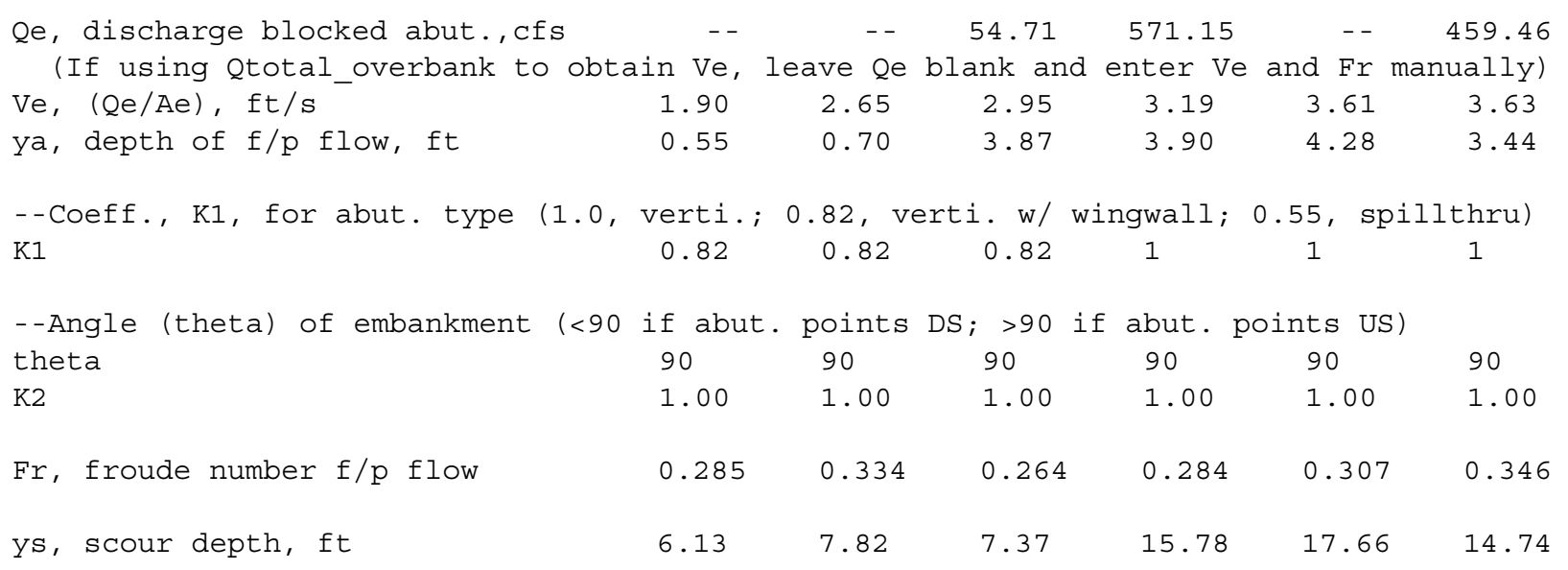

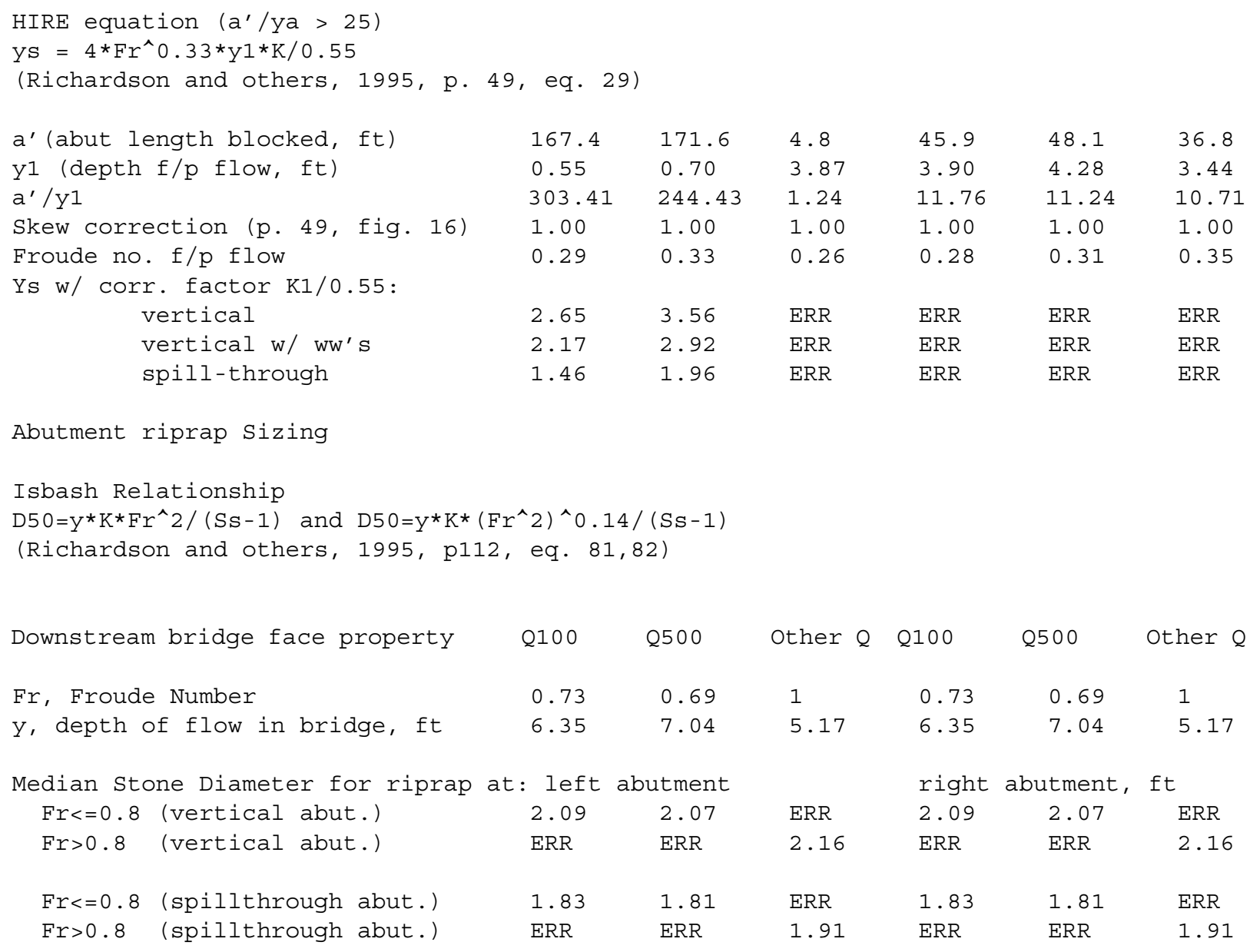


